\title{
18ß-Glycyrrhetinic Acid Has Anti-Cancer Effects via Inducing Apoptosis and G2/M Cell Cycle Arrest, and Inhibiting Migration of A549 Lung Cancer Cells
}

\author{
Ying-Hua Luo ${ }^{1, *}$ \\ Cheng Wang ${ }^{2, *}$ \\ Wan-Ting $\mathrm{Xu}^{3, *}$ \\ Yu Zhang ${ }^{3}$ \\ Tong Zhang ${ }^{3}$ \\ Hui Xue ${ }^{3}$ \\ Yan-Nan Li $\mathbb{1}^{3}$ \\ Zhong-Ren $\mathrm{Fu}^{3}$ \\ Ying Wang ${ }^{4}$ \\ Cheng-Hao Jin (iD) ${ }^{3-5}$
}

'Department of Grass Science, College of Animal Science and Veterinary Medicine, Heilongjiang Bayi Agricultural University, Daqing, 163319, People's Republic of China; ${ }^{2}$ Pharmacy Department, Daqing Oilfield General Hospital, Daqing, I6300I, People's Republic of China; ${ }^{3}$ Department of Biochemistry and Molecular Biology, College of Life Science \& Technology, Heilongjiang Bayi Agricultural University, Daqing, 163319, People's Republic of China; ${ }^{4}$ College of Food Science and Technology, Heilongjiang Bayi Agricultural University, Daqing, 163319, People's Republic of China; ${ }^{5}$ National Coarse Cereals Engineering Research Center, Daqing, 163319, People's Republic of China

*These authors contributed equally to this work

Correspondence: Cheng-Hao Jin; Ying Wang

Email jinchenghao3727@qq.com; wychen156@163.com

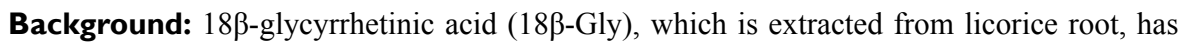
various pharmacological properties; however, its anti-cancer effects on lung cancer cells have not been fully established.

Purpose: In this study, we investigated the underlying molecular mechanisms of $18 \beta-G l y$. Results: Our results showed that $18 \beta$-Gly had significant cytotoxic effects and no apparent side effects. 18ß-Gly induced mitochondria-dependent apoptosis of A549 lung cancer cells. In addition, after treatment with $18 \beta$-Gly, intracellular reactive oxygen species (ROS) levels were significantly increased, and G2/M cell cycle arrest and inhibition of cell migration were induced via the mitogen-activated protein kinase (MAPK)/signal transducer and activator of transcription 3 (STAT3)/nuclear factor kappa (NF- $\kappa \mathrm{B})$ signaling pathways. After pretreatment with the ROS scavenger N-acetyl-L-cysteine or MAPK inhibitors, the expression levels of phosphorylated p38 (p-p38), phosphorylated c-Jun N-terminal kinase, inhibitor of nuclear factor kappa B, cleaved caspase-3 (cle-cas-3), cleaved poly (ADP ribose) polymerase (clePARP), p-p53, p27, p21, and E-cadherin were decreased; and levels of phosphorylated extracellular signal-regulated kinase, p-STAT3, NF-kB, Bcl-2, cyclin B1, cyclasedependent kinase 1/2 (CDK1/2), N-cadherin, vimentin, and snail homolog 1 (SNAI 1) were increased. In addition, the percentage of cells in the G2/M phase was decreased, and inhibition of migration was reduced.

Conclusion: In summary, 18ß-Gly induced apoptosis and G2/M cell cycle arrest and inhibited migration via the ROS/MAPK/STAT3/NF- $\mathrm{BB}$ signaling pathways in A549 lung cancer cells. Therefore, $18 \beta$-Gly is a novel promising candidate for the treatment of lung cancer.

Keywords: $18 \beta$-glycyrrhetinic acid, lung cancer, apoptosis, cell cycle arrest, ROS, cell migration

\section{Introduction}

Lung cancer is one of the most common malignant tumors, with a morbidity and mortality that has rapidly increased globally in recent decades. ${ }^{1}$ Despite advances in early detection and treatment strategies for lung cancer, the 5-year survival rate is still below $20 \%{ }^{2}$ Treatment options for lung cancer included surgery, chemotherapy, radiation therapy, or a combination. In addition, systemic chemotherapy is commonly used to treat advanced lung cancer by controlling symptoms and 
prolonging survival. ${ }^{3}$ Despite improved chemotherapy, long-term survival in patients with advanced lung cancer remains low. ${ }^{4}$ Therefore, it is important to study the pathogenesis and molecular mechanisms of lung cancer, and to identify novel therapeutic drugs with high anti-cancer efficacy and few side effects.

In recent years, natural compounds derived from traditional Chinese medicines have become a research hotspot in the development of highly effective anti-cancer drugs with few side effects. ${ }^{5,6} 18 \beta$-glycyrrhetinic acid (18ß-Gly) is the major bioactive component of Glycyrrhizae Radix, possessing antiulcerative, anti-inflammatory, and antiproliferative properties. $^{7-9}$ In addition, $18 \beta$-Gly inhibits migration and invasion via the reactive oxygen species (ROS)/ protein kinase $\mathrm{C}$-alpha/ERK pathways in human gastric cancer cells. ${ }^{10}$ However, to date, the effects of $18 \beta$-Gly on lung cancer remain unclear.

ROS, mainly produced by mitochondria, play an important role in various signaling pathways. ${ }^{11}$ Most research has focused on the regulatory relationship between ROS and downstream signaling pathways. ${ }^{12,13}$ Mitogen-activated protein kinase (MAPK) and p53 are two important downstream molecules regulated by ROS, and are involved in tumor migration, invasion, apoptosis, and cell cycle arrest. ${ }^{14,15}$ In addition, various ROS-related transcription factors are associated with the epithelialmesenchymal transition (EMT) such as snail homolog 1 (SNAI 1), E-cadherin, N-cadherin, and vimentin. ${ }^{16}$

In this study, we evaluated the effects of $18 \beta$-Gly on A549 lung cancer cells. We also investigated the potential molecular mechanisms of $18 \beta$-Gly in A549 cells, including the relationship of MAPK, signal transducer and activator of transcription 3 (STAT3), and other signaling pathways. The results of our study indicate that $18 \beta$-Gly may be a potential candidate for treating human lung cancer.

\section{Materials and Methods Chemicals and Reagents}

$18 \beta$-Gly was obtained from Herbpurify Co., Ltd. (purity $\geq$ 98\%; Chengdu, China), and it was dissolved with celllevel dimethyl sulfoxide (DMSO). The final concentration of DMSO is less than $0.5 \%$, which can rule out the cytotoxic effect of the solvent on the cells. The Mitochondrial Membrane Potential Assay Kit (JC-1), DNA Content Quantitation Assay, and Nuclear Protein Extraction Kit were obtained from Solarbio (Beijing,
China). Fetal bovine serum (FBS), Dulbecco's modified Eagle's medium (DMEM), Roswell Park Memorial Institute-1640 (RPMI-1640), penicillin, and streptomycin were purchased from Gibco (Waltham, MA, USA). Cell Counting Kit-8 (CCK-8), Apoptosis and Necrosis Assay Kit, Annexin V-FITC Apoptosis Detection Kit, and ROS Assay Kit were purchased from Beyotime Institute of Biotechnology (Shanghai, China). All of the antibodies were purchased from Santa Cruz Biotechnology, Inc. (Dallas, TX, USA). 5-Fluorouracil (5-FU, purity $\geq$ 99.86\%) and MAPK inhibitors (SB203580, inhibitor of p38; SP600125, inhibitor of c-Jun N-terminal kinase (JNK); FR180204, inhibitor of ERK) were obtained from MedChem Express (Princeton, NJ, USA). N-AcetylL-cysteine (NAC) and dimethyl sulfoxide were purchased from Sigma (St. Louis, MO, USA). Secondary antibodies were purchased from ZSGB-Bio, Inc. (Beijing, China).

\section{Cell Lines and Cell Culture}

A549, NCI-H23, and NCI-H460 human lung cancer cells (American Type Culture Collection, Manassas, VA, USA) were cultured in DMEM supplemented with $10 \%$ FBS, $100 \mathrm{U} / \mathrm{mL}$ penicillin, and $100 \mu \mathrm{g} / \mathrm{mL}$ streptomycin. IMR90 human embryonic lung fibroblasts, GES-1 human normal gastric cells, and 293T human embryonic kidney cells were maintained in RPMI-1640 medium (Saiqi Biotech Co., Ltd., Shanghai, China). All of the cells were cultured in humidified $5 \% \mathrm{CO}_{2}$ at $37^{\circ} \mathrm{C}$.

\section{CCK-8 Assay}

The CCK- 8 assay was used to determine cell viability following treatment with $18 \beta$-Gly. All of the cells were seeded at a density of $1 \times 10^{4}$ cells/well into 96-well culture plates, and then treated with 5-FU and 18ß-Gly at different concentrations $(10,20,30,40$, and $50 \mu \mathrm{M})$ for 24 $\mathrm{h}$ or different time points $(6,12,24$, and $36 \mathrm{~h})$ at the half maximal inhibitory concentration $\left(\mathrm{IC}_{50}\right)$. After incubation, $10 \mu \mathrm{L}$ CCK-8 solution was added to each well and incubated for $3 \mathrm{~h}$. The absorbance was detected at $450 \mathrm{~nm}$ by a microplate reader (BioTek Instruments Inc., Winooski, VT, USA).

\section{Cell Apoptosis Assay}

The apoptotic nuclear changes were determined by Hoechst 33342/propidium iodide (PI) double staining. A549 lung cancer cells were seeded at a density of $1 \times$ $10^{5}$ cells/well into 6-well culture plates, and treated with $15 \mu \mathrm{M} 18 \beta$-Gly for $3,6,12$, and $24 \mathrm{~h}$. Briefly, $5 \mu \mathrm{L}$ 
Hoechst staining solution and $2 \mu \mathrm{L}$ PI were added to each well, followed by incubation for $20 \mathrm{~min}$ at $4^{\circ} \mathrm{C}$. Then cells were washed once with phosphate-buffered saline (PBS), and observed using a fluorescence microscope (Thermo Fisher Scientific, Waltham, MA, USA). After treating a separate group of cells with $15 \mu \mathrm{M} 18 \beta$-Gly for 3, 6, 12 , and $24 \mathrm{~h}$, cells were collected and re-suspended in 195 $\mu \mathrm{L}$ Annexin V staining buffer. Subsequently, $3 \mu \mathrm{L}$ Annexin V-FITC and $2 \mu \mathrm{L}$ PI were added to the cells. After incubation at room temperature for $10 \mathrm{~min}$, the percentage of apoptotic cells was analyzed by flow cytometry (FCM; Beckman Coulter, Brea, CA, USA).

\section{Electron Microscopy}

The A549 cells were exposed to alcohol and immersed overnight in a fixator consisting of $1 \%$ glutaraldehyde and $4 \%$ paraformaldehyde at $4^{\circ} \mathrm{C}$. The cells were washed with PBS and fixed in 1\% osmium tetroxide. After immobilization, the ethanol was dehydrated and cells were embedded and polymerized. The cells were sectioned by ultramicrosection, stained with $1 \%$ uranyl acetate and lead citrate, and observed by transmission electron microscopy (TEM) (JEM-2100Plus; JEOL Ltd., Tokyo, Japan).

\section{Measurement of Mitochondrial Membrane Potential}

The change in mitochondrial membrane potential $\left(\Delta \psi_{\mathrm{m}}\right)$ in the A549 cells was detected by FCM after staining with JC-1. A549 cells were seeded in 6-well plates at a density of $1 \times 10^{5}$ cells/well, cultured for $24 \mathrm{~h}$, and then treated with $15 \mu \mathrm{M} 18 \beta$-Gly for $3,6,12$, and $24 \mathrm{~h}$. After centrifugation at $5000 \times \mathrm{g}$ for $6 \mathrm{~min}$ at room temperature, the collected cells were stained with $\mathrm{JC}$ - for $30 \mathrm{~min}$ at $37^{\circ} \mathrm{C}$. Then cells were washed twice with $1 \times \mathrm{JC}$ staining buffer solution ( $3 \mathrm{~min} /$ time), and the data were analyzed by FCM.

\section{Nuclear Extract Preparation}

The Nuclear Protein Extraction Kit was used to prepare the nuclear extracts. Briefly, A549 cells were treated with $15 \mu \mathrm{M} 18 \beta$-Gly for $3,6,12$, and $24 \mathrm{~h}$, and then collected at $500 \times \mathrm{g}$ for $3 \mathrm{~min}$. Then the cells were re-suspended with $80 \mu \mathrm{L}$ plasma protein extraction reagent and incubated on ice for $10 \mathrm{~min}$. Cells were centrifuged at $12,000 \times \mathrm{g}$ for 10 $\min$ at $4{ }^{\circ} \mathrm{C}$, and the supernatants contained the cytosolic extract. The precipitate was resuspended in $50 \mu \mathrm{L}$ nuclear protein extraction reagent and incubated on ice for $10 \mathrm{~min}$, followed by centrifugation at $12,000 \times \mathrm{g}$ for $10 \mathrm{~min}$ at $4^{\circ} \mathrm{C}$. The supernatants contained the nuclear proteins.

\section{Western Blot Analysis}

The expression levels of proteins were detected by Western blotting. Treated cells were collected and suspended in protein lysis buffer for at least $30 \mathrm{~min}$ on ice. Cell lysates were clarified by centrifugation at $12,000 \times$ $\mathrm{g}$ for $30 \mathrm{~min}$ at $4^{\circ} \mathrm{C}$, and the supernatants were mixed with $5 \times$ buffer and boiled for $5 \mathrm{~min}$. An equal amount of protein $(30 \mu \mathrm{g})$ was loaded onto $8-12 \%$ SDS-PAGE gels and electrotransferred to nitrocellulose membranes (Billerica, MA, USA). Then the membranes were blocked in 5\% nonfat skim milk and probed with primary antibodies. After washing, the membranes were incubated with horseradish peroxidase-conjugated secondary antibodies. Proteins were visualized by enhanced chemiluminescence (Bio-Rad, Hercules, CA, USA) and quantified with ImageJ version $1.42 \mathrm{q}$.

\section{Measurement of ROS Levels}

Intracellular ROS levels were measured using the fluorescent probe $2^{\prime}, 7^{\prime}$-dichlorofluorescein diacetate (DCFH-DA). A549 cells and IMR-90 human embryonic lung fibroblasts were treated with $15 \mu \mathrm{M} 18 \beta$-Gly for $3,6,12$, and $24 \mathrm{~h}$, and then incubated with $10 \mu \mathrm{M}$ DCFH-DA for $20 \mathrm{~min}$ at $37^{\circ} \mathrm{C}$. After incubation, cells were collected and washed with PBS. Intracellular ROS levels were analyzed by FCM.

\section{Analysis of Cell Cycle Arrest}

The cell cycle arrest of A549 cells was detected by PI staining. A549 cells were treated with $15 \mu \mathrm{M} 18 \beta$-Gly for $3,6,12$, and $24 \mathrm{~h}$. Then, $1 \times 10^{5}$ cells were collected at $2000 \times \mathrm{g}$ for $5 \mathrm{~min}$ and washed with PBS. Cells were fixed in cold $70 \%$ ethanol for $4 \mathrm{~h}$ and incubated with $100 \mu \mathrm{L}$ RNase A solution for $30 \mathrm{~min}$ at $37^{\circ} \mathrm{C}$. Then the cells were incubated with $400 \mu \mathrm{L}$ PI for $30 \mathrm{~min}$ at $4^{\circ} \mathrm{C}$ in the dark, followed by cell cycle analysis by FCM.

\section{Wound Healing Assay}

The wound healing assay was used to detect cell migration. A549 cells were seeded in 24-well plates at a density of $3 \times 10^{5}$ cells/well. When the cell density was $>90 \%$, scratches were created in the cell cultures using a $10 \mu \mathrm{L}$ micropipette tip and PBS was used to remove dislodged cells. Cells were treated with $15 \mu \mathrm{M} 18 \beta$-Gly for 3, 6, 12, and $24 \mathrm{~h}$, and the wound closure images representing cell 
migration were observed with an inverted microscope. The gap area was quantified by ImageJ version 1.42q.

\section{Transwell Migration Assay}

The Transwell assay was used to detect cell migration. A549 cells were seeded in 12-well plates at a density of $1 \times 10^{6}$ cells/well. Cells were added to the upper chamber with serum-free DMEM medium, while the medium with $10 \%$ FBS was placed in the lower chamber as a chemoattractant. Cells were treated with $15 \mu \mathrm{M} 18 \beta$ Gly for $3,6,12$, and $24 \mathrm{~h}$, cells were stained by $0.1 \%$ crystal violet solution and then counted via microscope.

\section{Statistical Analysis}

Statistical analysis was performed using SPSS version 21.0. All of the results are presented as the mean \pm standard deviation (SD) of at least three replicates. The $t$-test was used to compare the means of two groups and oneway analysis of variance was used to compare more than two groups. $P<0.05$ was considered to be statistically significant.

\section{Results}

\section{I8 $\beta$-Gly Inhibits the Proliferation of Lung Cancer Cells}

To determine the cytotoxic effects of 18 $\beta$-Gly, three lung cancer cell lines (A549, NCI-H23, NCI-H460) and three human normal cell lines (IMR-90, GES-1, $293 \mathrm{~T}$ ) were treated with 5 -FU or $18 \beta$-Gly, and the cell viability was determined by the CCK- 8 assay. As shown in Figures $1 \mathrm{~A}$ and $\mathrm{C}$, the viabilities of three lung cancer cell lines (A549, NCI-H23, NCI-H460) were more significantly decreased in concentrationand time-dependent manners by $18 \beta$-Gly than by 5 -FU $(\mathrm{p}<0.001)$. In addition, the viabilities of three normal cell lines (IMR-90, GES-1, 293T) were also more significantly decreased with $18 \beta$-Gly compared to 5-FU ( $p<0.01$; Figures $1 \mathrm{~B}$ and $\mathrm{D})$. When lung cancer cells were treated with $18 \beta$-Gly for $36 \mathrm{~h}$, a large amount of cells were apoptotic and detached from the plate, so this time point was not used in subsequent experiments. When the lung cancer cells were treated with $18 \beta$-Gly for $24 \mathrm{~h}$, the $\mathrm{IC}_{50}$ (Table 1) was reached, so the time points chosen for subsequent experiments were $0,3,6,12$, and $24 \mathrm{~h}$.

\section{I8ß-Gly Induces Apoptosis in Lung Cancer A549 Cells}

To determine the pro-apoptotic effects of 18ß-Gly on A549 cells, apoptotic nuclear changes were measured by Hoechst 33342/PI double staining. As shown in Figure 2A, the fluorescence intensity of the A549 cells gradually increased and cells became swollen and broken. FCM was used to further detect the apoptosis of A549 cells. The percentage of A549 cells was increased in a timedependent manner $(p<0.001$; Figure $2 B$ ). During the process of cell apoptosis, a series of changes in mitochondria occur under the stimulation of apoptotic factors. Therefore, we observed the changes in the mitochondria of cells by TEM, FCM was used to detect the $\Delta \psi_{\mathrm{m}}$, and Western blotting was used to detect changes in related apoptotic factors. The mitochondria was deformed and swollen; the $\Delta \psi_{\mathrm{m}}$ was gradually decreased; expression of the pro-apoptotic factors B-cell lymphoma 2 (Bcl-2)associated agonist of cell death (Bad), cytochrome C (Cyto C), cleaved-caspase-3 (cle-cas-3), and cleavedpoly (ADP ribose) polymerase (cle-PARP) were gradually increased; and expression of the anti-apoptotic factor Bcl2 was gradually decreased (Figure $2 \mathrm{C}-\mathrm{E}$ ). These results indicate that $18 \beta$-Gly induces the mitochondria-dependent apoptosis of A549 cells.

\section{I8ß-Gly Promotes Apoptosis via MAPK/ STAT3/NF- $\kappa B$ Signaling Pathways in A549 Lung Cancer Cells}

To determine the mechanisms underlying the induction of apoptosis of A549 lung cancer cells by 18ß-Gly, the expression levels of MAPK/STAT3/NF- $\mathrm{kB}$ signaling pathway-related proteins were detected by Western blotting. The expression levels of p-ERK, p-STAT3, and NF- $\mathrm{KB}$ were decreased; and levels of phosphorylated (p-p38), p-JNK, and inhibitor of nuclear factor kappa B (ІкB- $\alpha$ ) were increased (Figure 3A). As nuclear transcription factors, STAT3, NF- $\kappa B$, and $\mathrm{p}-\mathrm{I} \kappa \mathrm{B}$ are required for nuclear transport. Briefly, the expression levels of STAT3, NF- $\kappa B$, and $\mathrm{p}$-IкB were decreased (Figure $3 \mathrm{~B}$ ). These data demonstrated that $18 \beta$-Gly promoted apoptosis via MAPK/ STAT3/NF- $\kappa B$ signaling pathways in A549 cells. To determine the upstream and downstream relationship between MAPK and STAT3 signaling pathways in 18ß-Glyinduced apoptosis, A549 cells were pre-treated with three MAPK inhibitors (SB203580, p38 inhibitor; SP600125, JNK inhibitor; and FR180204, ERK inhibitor), and the 
A

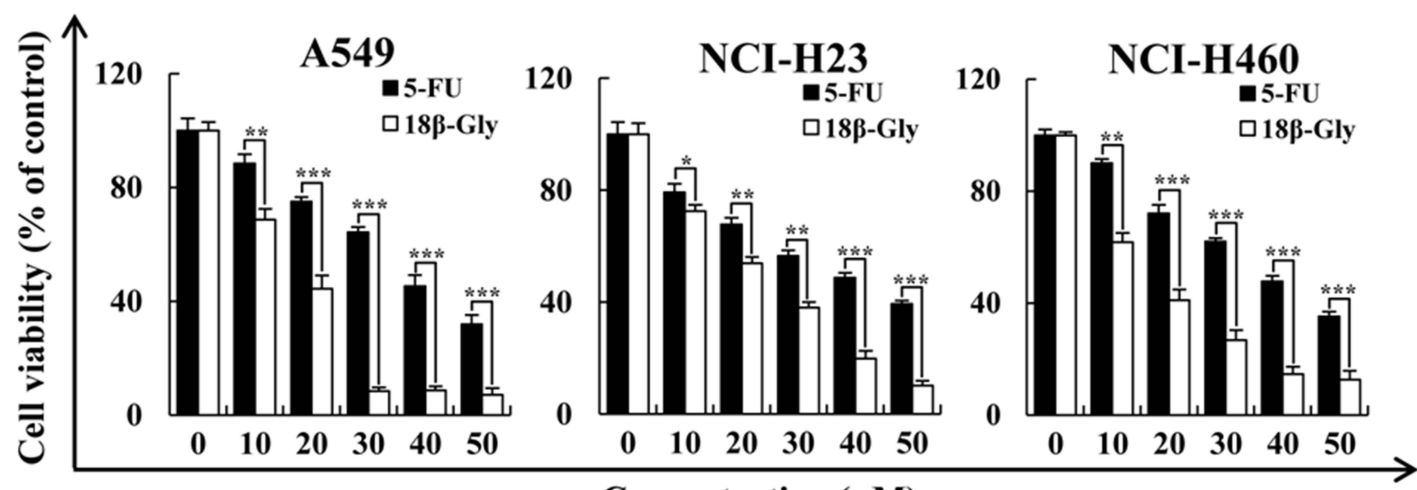

B

Concentration $(\mu \mathrm{M})$
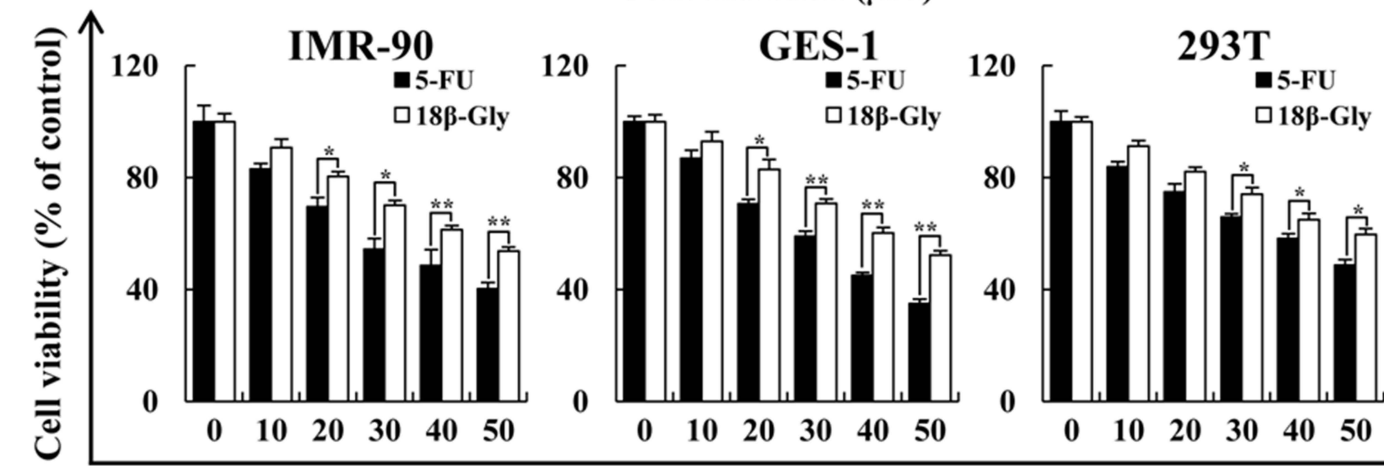

C

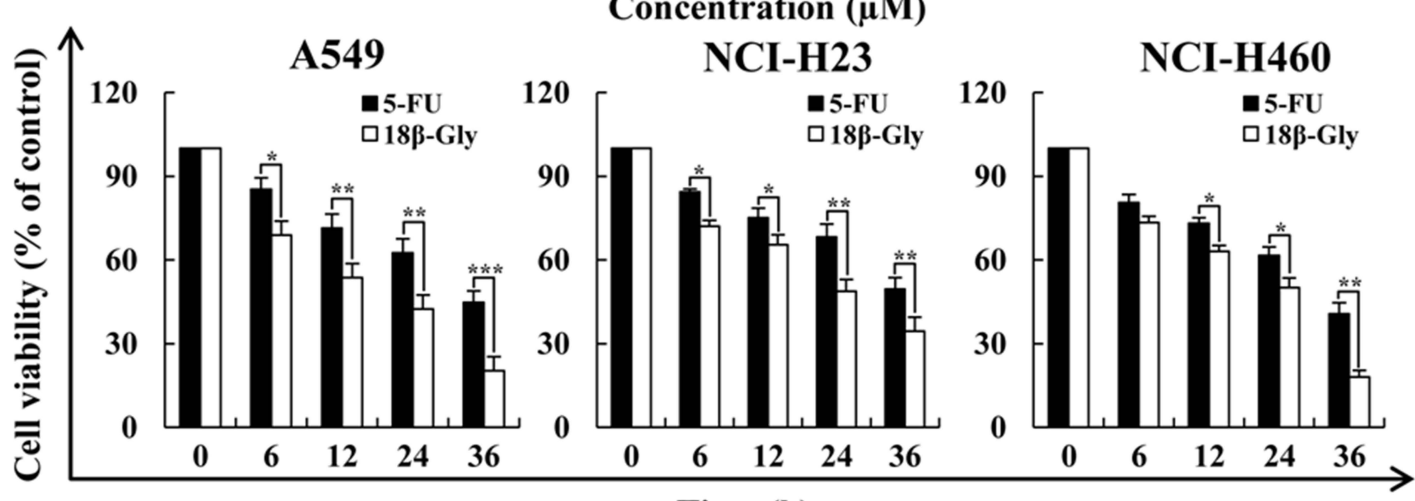

D

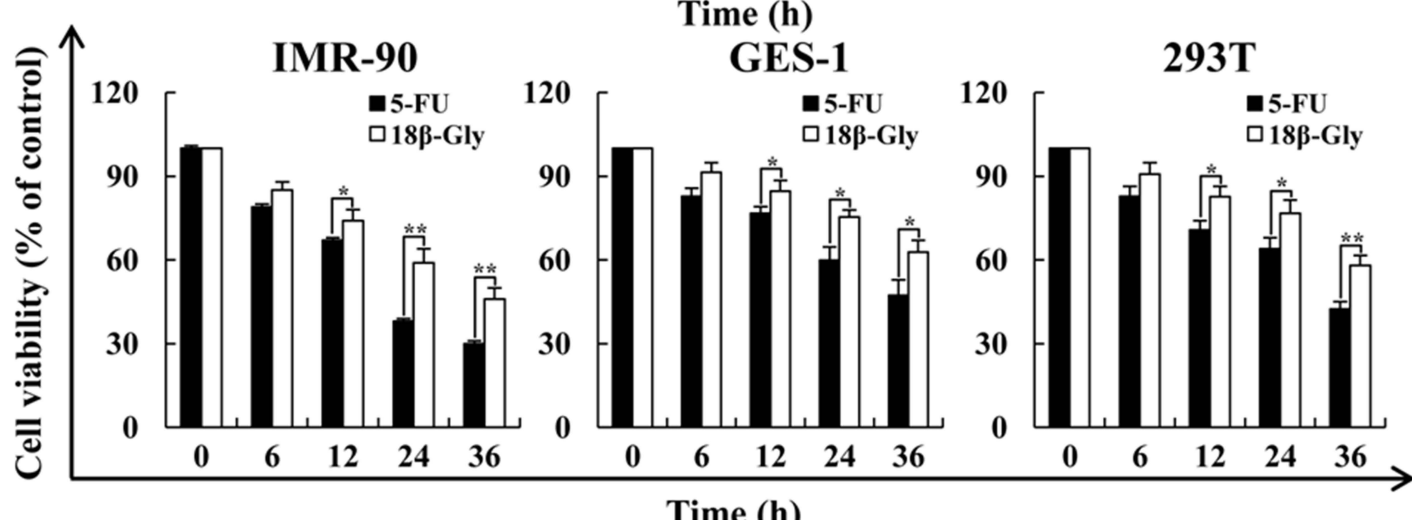

Figure I Cytotoxic effects of $18 \beta-\mathrm{Gly}$ on human lung cancer cells. (A) $\mathrm{A} 549, \mathrm{NCl}-\mathrm{H} 23$, and $\mathrm{NCl}-\mathrm{H} 460$ lung cancer cells were treated with different concentrations of I8 3 Gly $(10,20,30,40$, and $50 \mu \mathrm{M})$ for $24 \mathrm{~h}$, after which their cell viabilities were determined by the CCK-8 assay. (B) IMR-90, GES-I, and 293T normal cells were treated with different concentrations of I8ß-Gly $(\mathrm{I0}, 20,30,40$, and $50 \mu \mathrm{M})$ for $24 \mathrm{~h}$, after which their cell viabilities were determined by the CCK-8 assay. (C) A549, $\mathrm{NCl}-\mathrm{H} 23$, and $\mathrm{NCl}$ $\mathrm{H} 460$ cells were treated at different time points $(6,12,24$, and $36 \mathrm{~h})$ with IC 50 of I8 8 -Gly, after which their cell viabilities were determined by the CCK-8 assay. (D) IMR-90, GES-I and $293 \mathrm{~T}$ cells were treated at different time points $(6,12,24$, and $36 \mathrm{~h})$ with IC 50 of I8ß-Gly, after which their cell viabilities were determined by the CCK-8 assay. Data are expressed as the means \pm SDs. $* P<0.05$, $* * P<0.01$, $* * * p<0.001$ vs control. 
Table I IC 50 Values of I8ß-Gly and 5-FU in Lung Cancer Cells

\begin{tabular}{|c|c|c|}
\hline Cell Line & 5-FU $(\mu M)$ & I8ß-Gly $(\mu \mathrm{M})$ \\
\hline A549 & $36.83 \pm 1.87$ & $15.73 \pm 1.47$ \\
\hline $\mathrm{NCl}-\mathrm{H} 23$ & $40.84 \pm 1.83$ & $24.92 \pm 1.18$ \\
\hline $\mathrm{NCl}-\mathrm{H} 460$ & $39.17 \pm 2.26$ & $18.38 \pm 1.52$ \\
\hline
\end{tabular}

Note: The $\mathrm{IC}_{50}$ values were calculated using GraphPad Prism software.

expression levels of MAPK, STAT3 were detected by Western blotting. After pretreatment with p38 and JNK inhibitors, compared with the $18 \beta$-Gly group, the expression levels of p-p38, p-JNK, cle-cas-3, and cle-PARP were decreased; and p-STAT3 and Bcl-2 were increased in the $18 \beta$-Gly + inhibitor group (Figures $3 \mathrm{C}$ and D). In addition, after pre-treatment with ERK inhibitors, compared with the 18 $\beta$-Gly group, the expression levels of p-ERK, p-STAT3, and Bcl-2 were decreased; and those of cle-cas -3 and cle-PARP were increased in the $18 \beta$-Gly + inhibitor group (Figure 3E). These results indicate that MAPK regulates the STAT3 signaling pathway in 18 $\beta$-Glytreated A549 cells.

\section{I8ß-Gly Induces Apoptosis via ROS- Mediated MAPK/STAT3/NF- $\kappa B$ Signaling Pathways in A549 Lung Cancer Cells}

When cells undergo apoptosis, the function and structure of the mitochondria are changed, which led to an increase in intracellular ROS levels. Therefore, to investigate the changes in ROS levels in 18ß-Gly-treated A549 cells, the intracellular ROS levels were detected by FCM. As shown in Figures 4A and B, the intracellular ROS levels in A549 cells increased in a time-dependent manner after $18 \beta$-Gly treatment. But in IMR-90 human embryonic lung fibroblasts, the intracellular ROS levels were decreased. After pretreatment with NAC, apoptosis was detected by FCM and the changes in mitochondrial morphology were observed by TEM. Compared with the $18 \beta$-Gly group, apoptosis of the $18 \beta$-Gly + NAC group was significantly decreased $(p<0.001$; Figure 4C). Briefly, compared with the $18 \beta$-Gly group, partial mitochondrial morphology of the $18 \beta$-Gly + NAC group returned to normal (Figure 4D). In addition, to determine whether 18 $\beta$-Gly regulates MAPK/STAT3/NF- $\mathrm{KB}$ signaling pathways by upregulating intracellular ROS levels, the expression of related signaling pathway protein levels were detected by Western blotting after pretreatment with NAC. As demonstrated in Figure 4E, compared with the 18ß-Gly group, the expression levels of p-p38, p-JNK, IкB- $\alpha$, cle-cas-3, and cle-PARP of $18 \beta$-Gly + NAC group were decreased; and the expression levels of p-ERK, p-STAT3, NF- $\kappa \mathrm{B}$, and Bcl-2 in the $18 \beta$-Gly + NAC group were increased.

\section{I8ß-Gly Induces G2/M Cell Cycle Arrest by ROS in Lung Cancer A549 Cells}

To verify the effects of $18 \beta$-Gly on cell cycle arrest in A549 cells, the cell cycle was measured by FCM and the expression levels of cell cycle protein were measured by Western blotting. The populations of cells in the G1 phase were gradually decreased, and the numbers of cells in the $\mathrm{G} 2 / \mathrm{M}$ phase were gradually increased (Figure 5A). Furthermore, the protein expression levels of p-p53, p27, and p21 were increased; and levels of cyclin $\mathrm{B} 1$ and $\mathrm{CDK} 1 / 2$ were decreased (Figure 5B). To further explore the role of ROS in G2M cell cycle arrest after treatment with $18 \beta$-Gly, we pre-treated cells with NAC. The percentage of A549 cells in the $\mathrm{G} 2 / \mathrm{M}$ phase was detected by FCM, and the expression levels of G2/M cell cycle-related proteins were measured by Western blotting (Figures 5C and D). After pretreatment with NAC, compared with the 18$\beta$-Gly group, the percentage of cells in the G2/M phase cells of the $18 \beta-G l y+N A C$ group was decreased $(\mathrm{p}<0.001$; Figure $6 \mathrm{C})$. The expression levels of p-p53, p27, and p21 of the 18ß-Gly+NAC group were decreased; and the levels of cyclin $\mathrm{B} 1$ and $\mathrm{CDK} 1 / 2$ of the $18 \beta$-Gly+NAC group were increased.

\section{I8ß-Gly Inhibits Cell Migration via the MAPK Signaling Pathway}

Cancer cell metastasis is the leading cause of cancerrelated death; thus, inhibiting cancer cell migration could prolong the survival of cancer patients. Therefore, transwell assay was used to detect cell migration. As shown in Figures 6A, 18 $\beta$-Gly significantly inhibited the migration of A549 cells in a time-dependent manner. Then, we used the wound healing assay to explore the effects of $18 \beta$-Gly on the migration of A549 cells. Compared with the control group, the $18 \beta$-Gly+NAC group had significantly inhibited cell migration $(\mathrm{p}<0.001$; Figure $6 \mathrm{~B})$. Next, the related migrating protein expression levels were evaluated by Western blotting. As demonstrated in Figure 6C, the expression levels of E-cadherin were increased; and those of N-cadherin, vimentin, and SNAI 1 were decreased in a time-dependent manner. In addition, compared with the $18 \beta$-Gly group, the relative migration distance of the $18 \beta$-Gly+NAC group was increased; the expression levels 
A
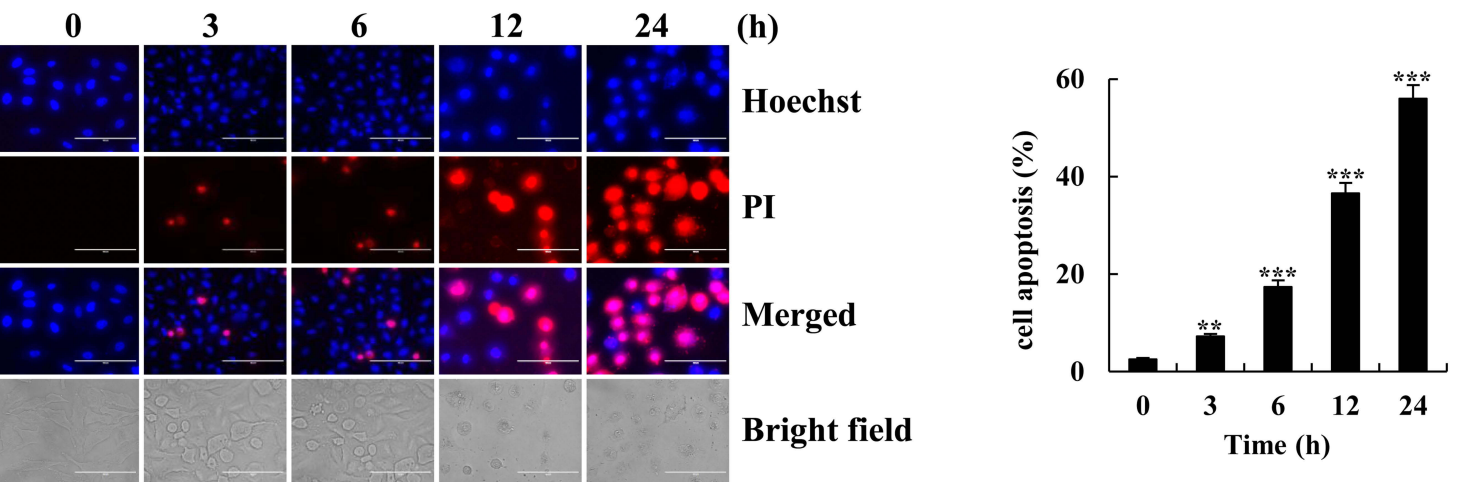

B
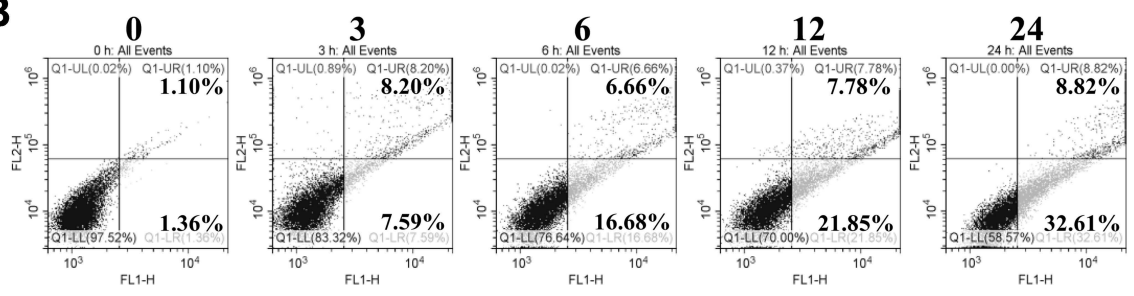

(h)

C

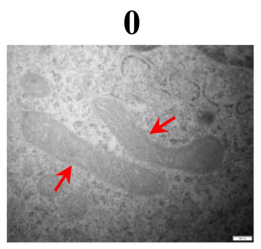

3

6
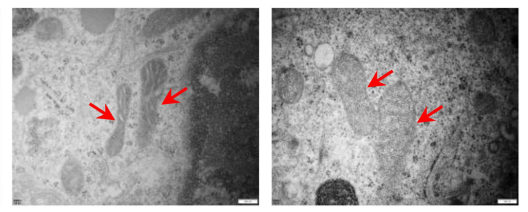

12

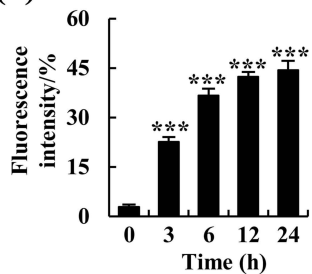

24

(h)

D

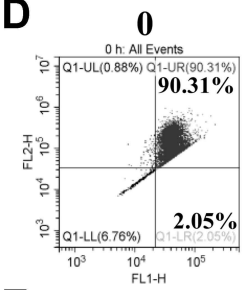

E
3

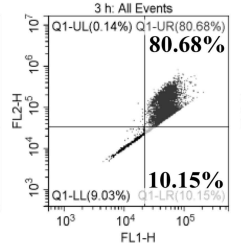

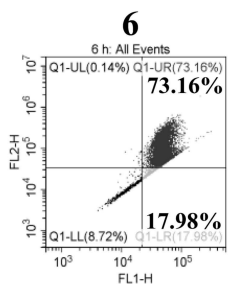
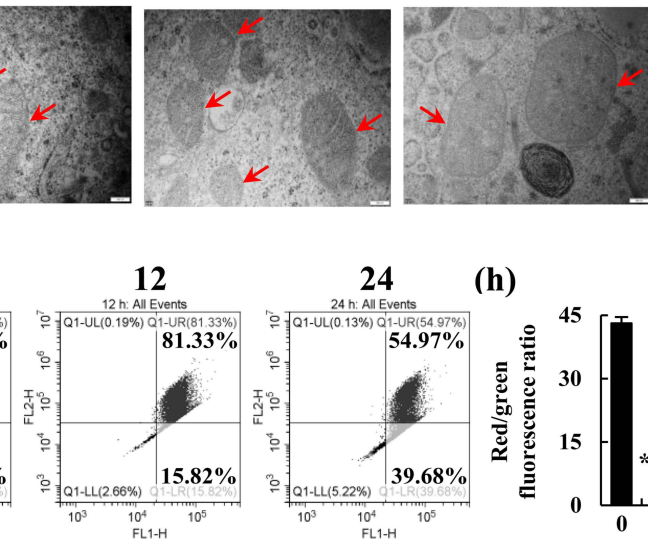

24

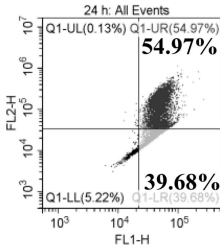

(h)
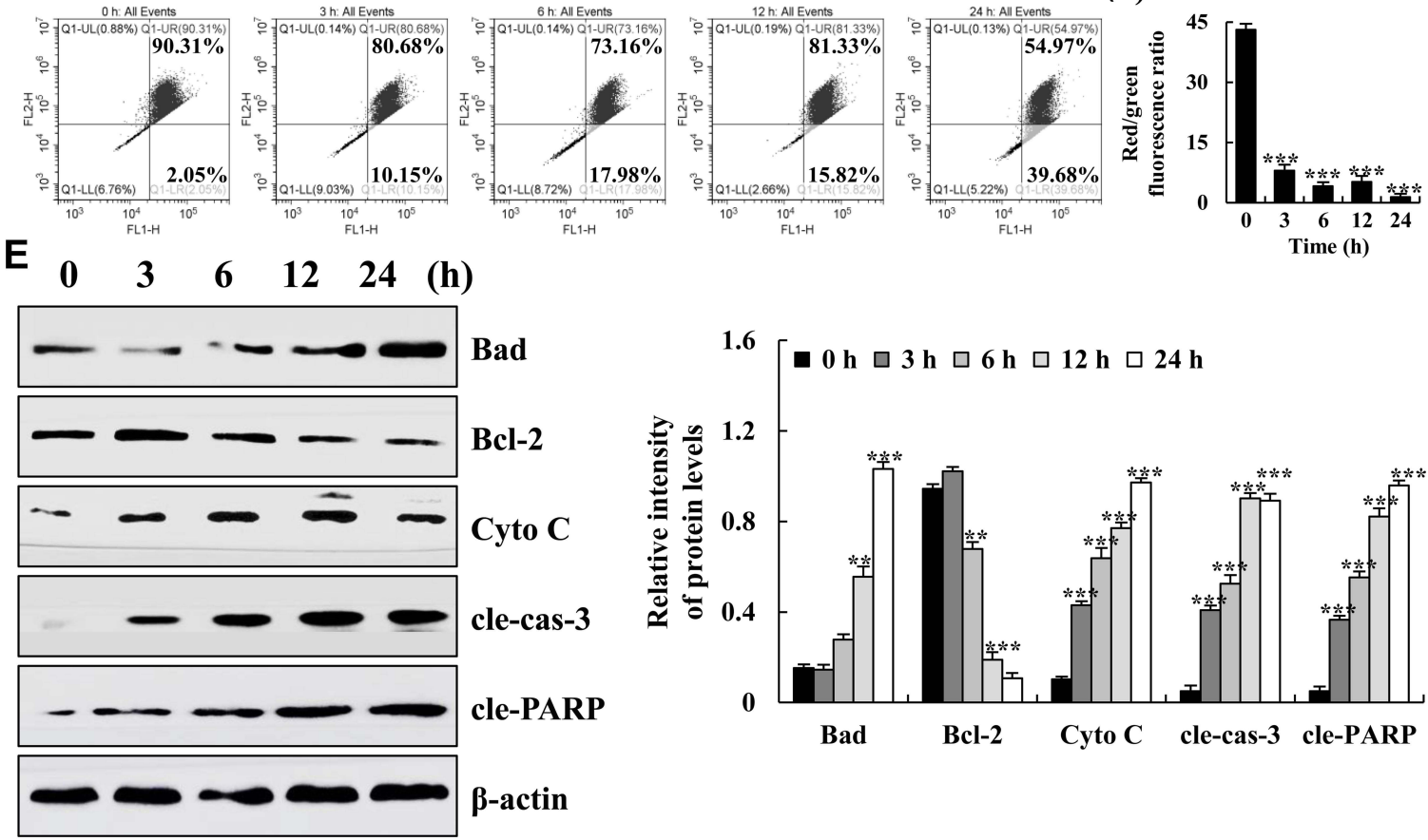

Bad

Bcl-2

Cyto C

cle-cas-3

cle-PARP

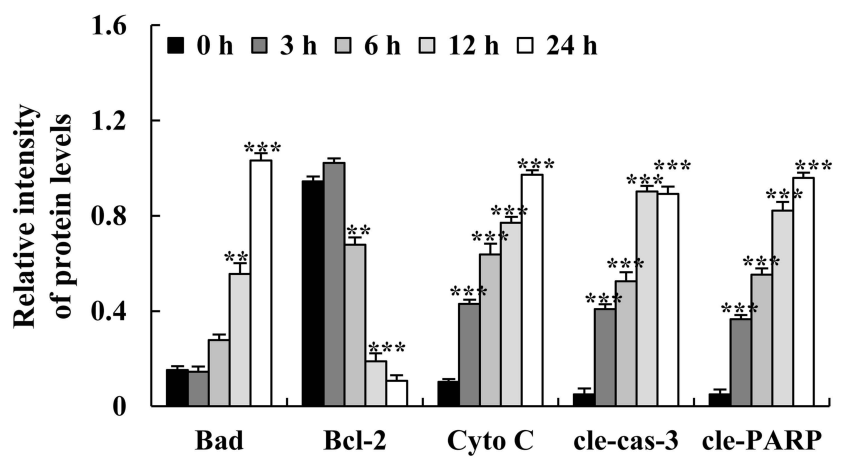

$\beta$-actin

Figure 2 Apoptotic effects of I8ß-Gly on A549 cells. (A) A549 cells were double stained with Hoechst 33342 and PI, and the fluorescence intensities and morphology changes were observed under a fluorescence microscope (original magnification, 200x). (B) Percentage of apoptotic cells was detected by flow cytometry. (C) Mitochondrial morphology was observed by an electron microscope, the morphological changes of mitochondria occurred at the arrow marks. (D) The MMP was detected by FCM. (E) The protein expression levels were measured by Western blotting after treatment of A549 cells with 18 $\beta$-Gly. The percentage of apoptotic cells represents the means \pm SDs. $\beta$-actin served as the loading control. $* * P<0.0 \mathrm{I}$, $* * * P<0.00 \mathrm{I}$ vs $0 \mathrm{~h}$. 

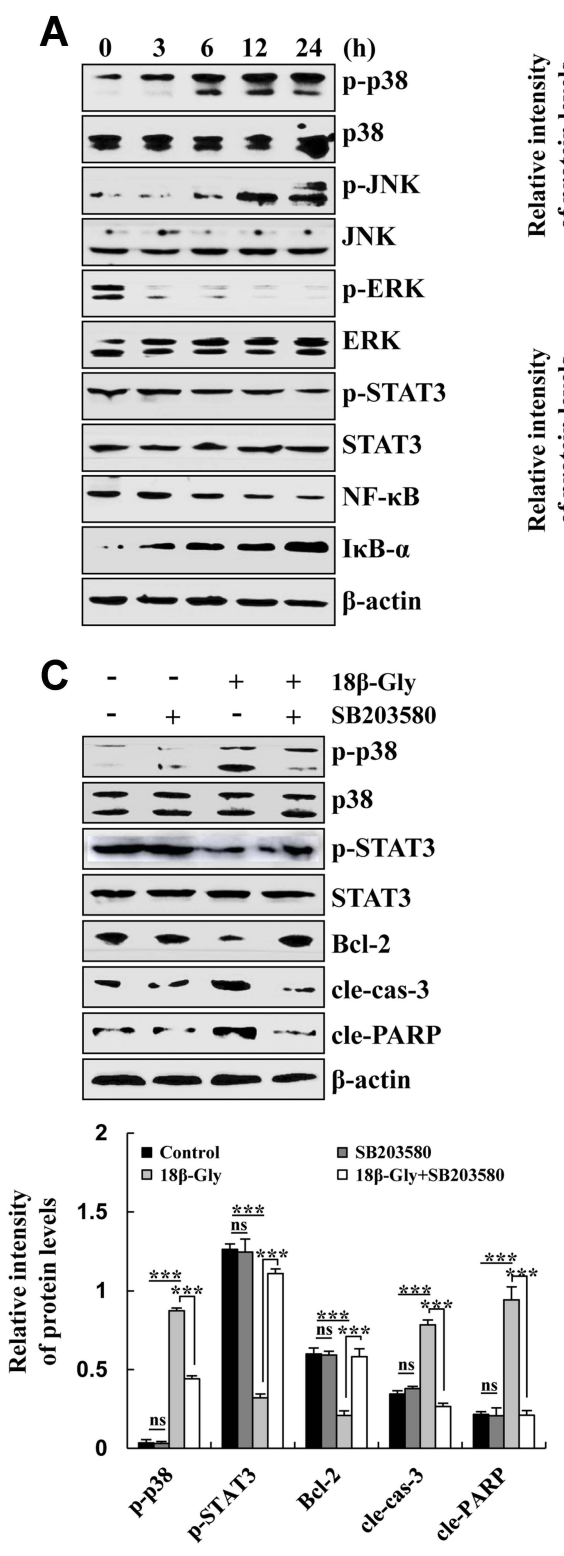
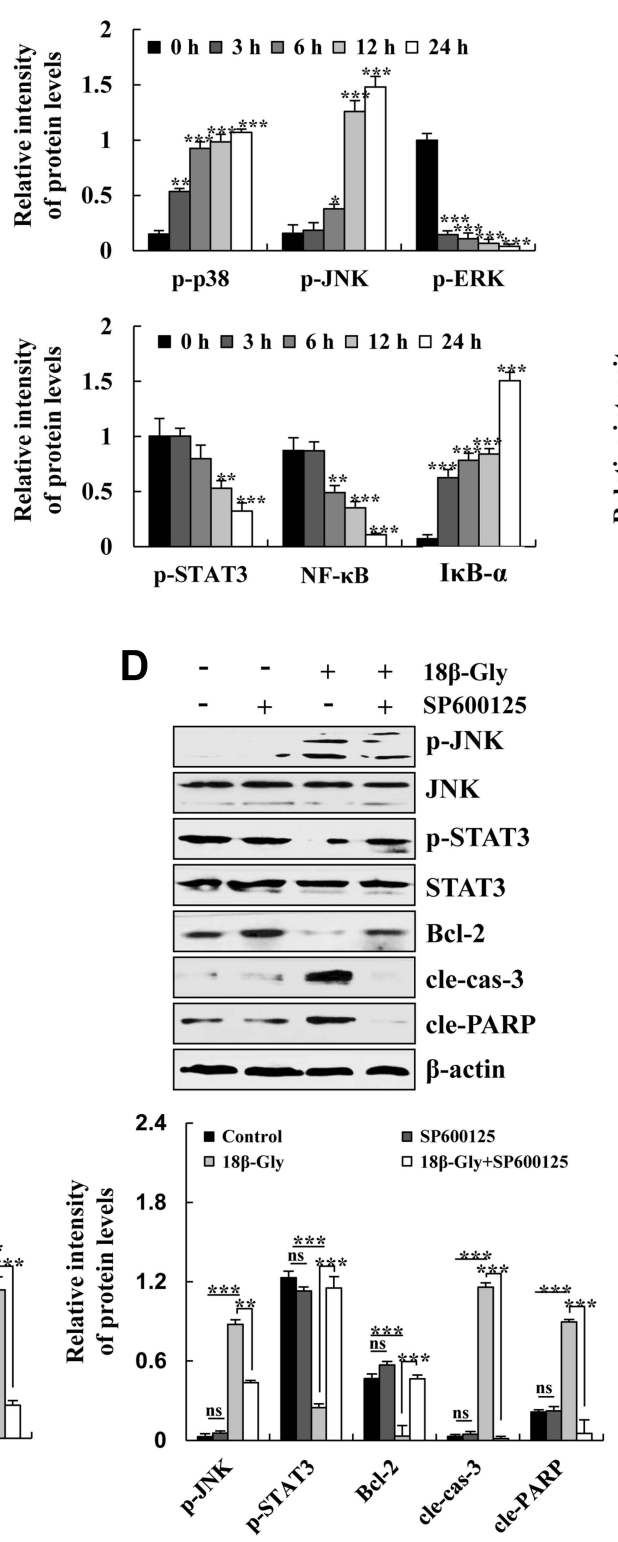
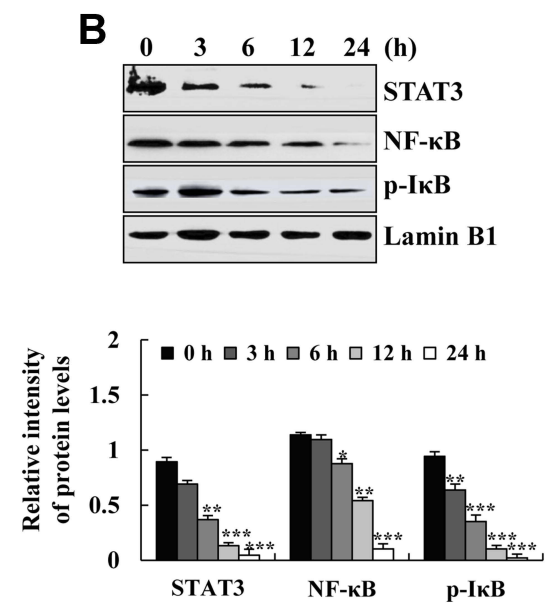

\section{E}
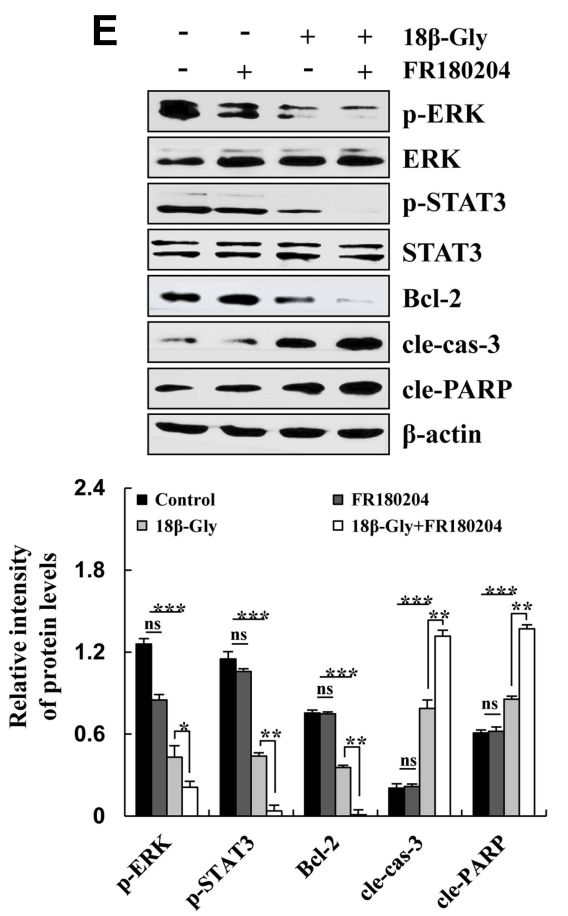

Figure 3 Effects of $18 \beta-$ Gly on MAPK/STAT3/NF- $\kappa B$ signaling pathways in A549 cells. (A) Expression levels of $p-p 38, p-J N K, p-E R K, p-S T A T 3, N F-\kappa B$, and IKB- $\alpha$ were measured by Western blotting. (B) Expression levels of STAT3, NF- $\kappa B$, and $p-1 \kappa B$ in the nucleus were measured by Western blotting. (C) Expression levels of $p-p 38$, p-STAT3, Bcl-2, cle-cas-3, and cle-PARP proteins in I8 3 -Gly and p38 inhibitor-treated A549 cells. (D) Expression levels of p-JNK, p-STAT3, Bcl-2, cle-cas-3, and cle-PARP proteins in I8 $\beta$-Gly and JNK inhibitor-treated A549 cells. (E) Expression levels of p-ERK, p-STAT3, Bcl-2, cle-cas-3, and cle-PARP proteins in I8 $\beta$-Gly- and ERK inhibitortreated A549 cells. $\beta$-actin and Lamin BI were served as the loading controls. $* P<0.05$, $* * P<0.0$, $* * * P<0.00 \mathrm{I}$ vs $0 \mathrm{~h}$ or I8 3 -Gly + MAPK inhibition.

of E-cadherin of the 18ß-Gly+NAC group were decreased, and the expression levels of $\mathrm{N}$-cadherin, vimentin, and SNAI 1 of the $18 \beta$-Gly+NAC group were increased (Figures 6D and E). The MAPK signaling pathway regulates cell migration, so we pre-treated cell with MAPK inhibitors and the expression levels of migrated proteins were measured by Western blotting. As Compared with the $18 \beta$-Gly group, the expression level of E-cadherin of the $18 \beta$-Gly+inhibitors group was decreased, and the expression level of N-cadherin, vimentin, and SNAI 1 of the $18 \beta$ -
Gly+inhibitor group was increased (Figures $6 \mathrm{~F}$ and $\mathrm{G}$ ). Furthermore, compared with the $18 \beta$-Gly group, the expression level of E-cadherin of the 18ß-Gly+FR180204 group was increased, and the expression levels of $\mathrm{N}$-cadherin, vimentin, and SNAI 1 of the $18 \beta$-Gly+inhibitor group were decreased (Figure 6H).

\section{Discussion}

$18 \beta$-Gly is one of the key bioactive components of licorice root, and it has been used in Chinese medicine to treat 
A

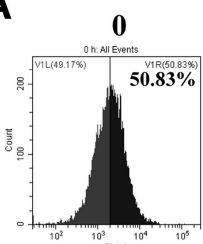

B

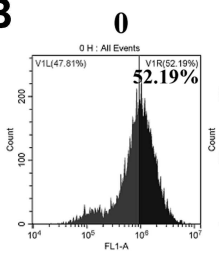

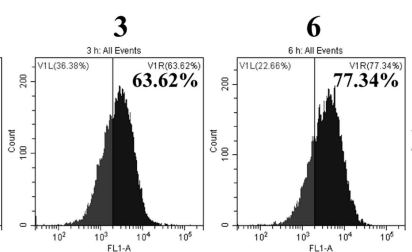

3
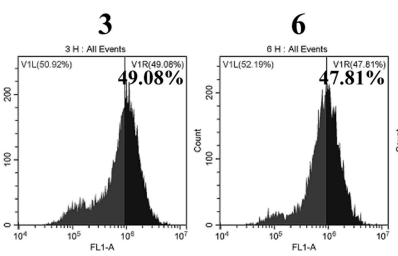

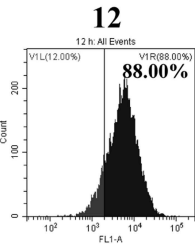

12
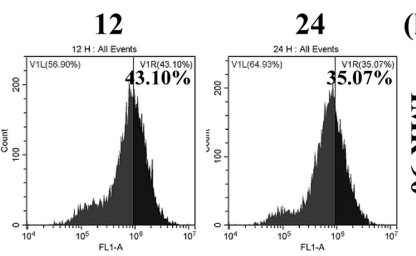

C
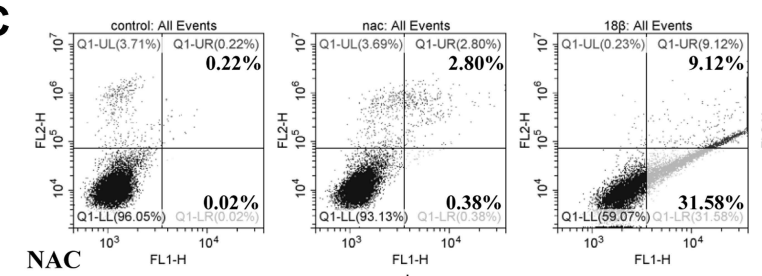

18ß-Gly -

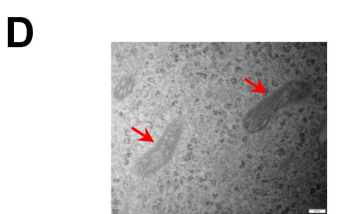

NAC

18B-Gly

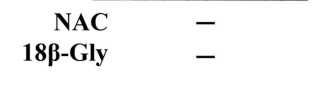

E

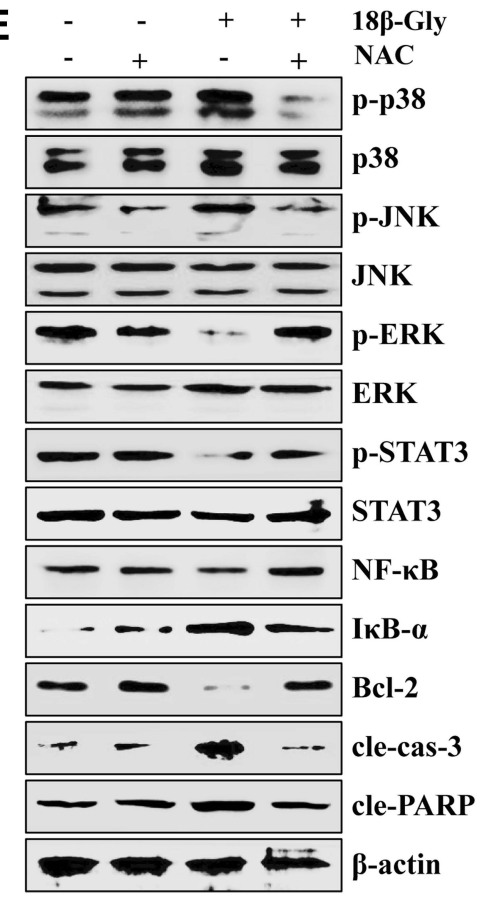

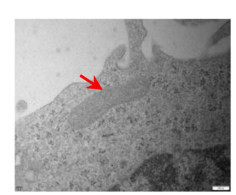

$+$

$\stackrel{+}{-}$

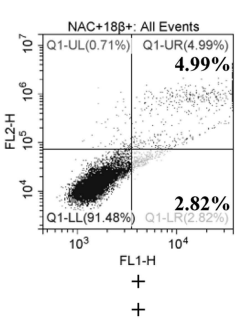

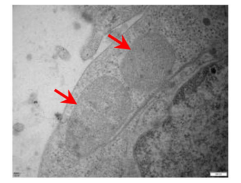

-

$+$

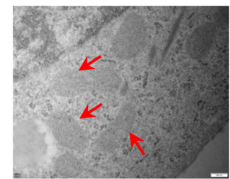

$+$

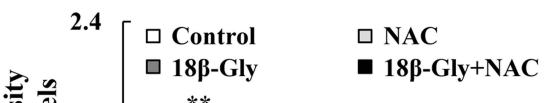

24

24

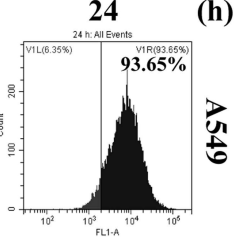

(h)

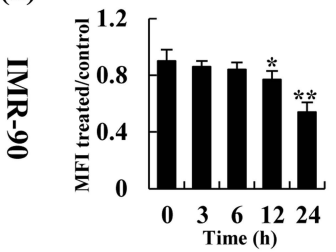

(h)

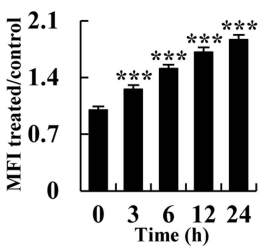

至 Time (h)
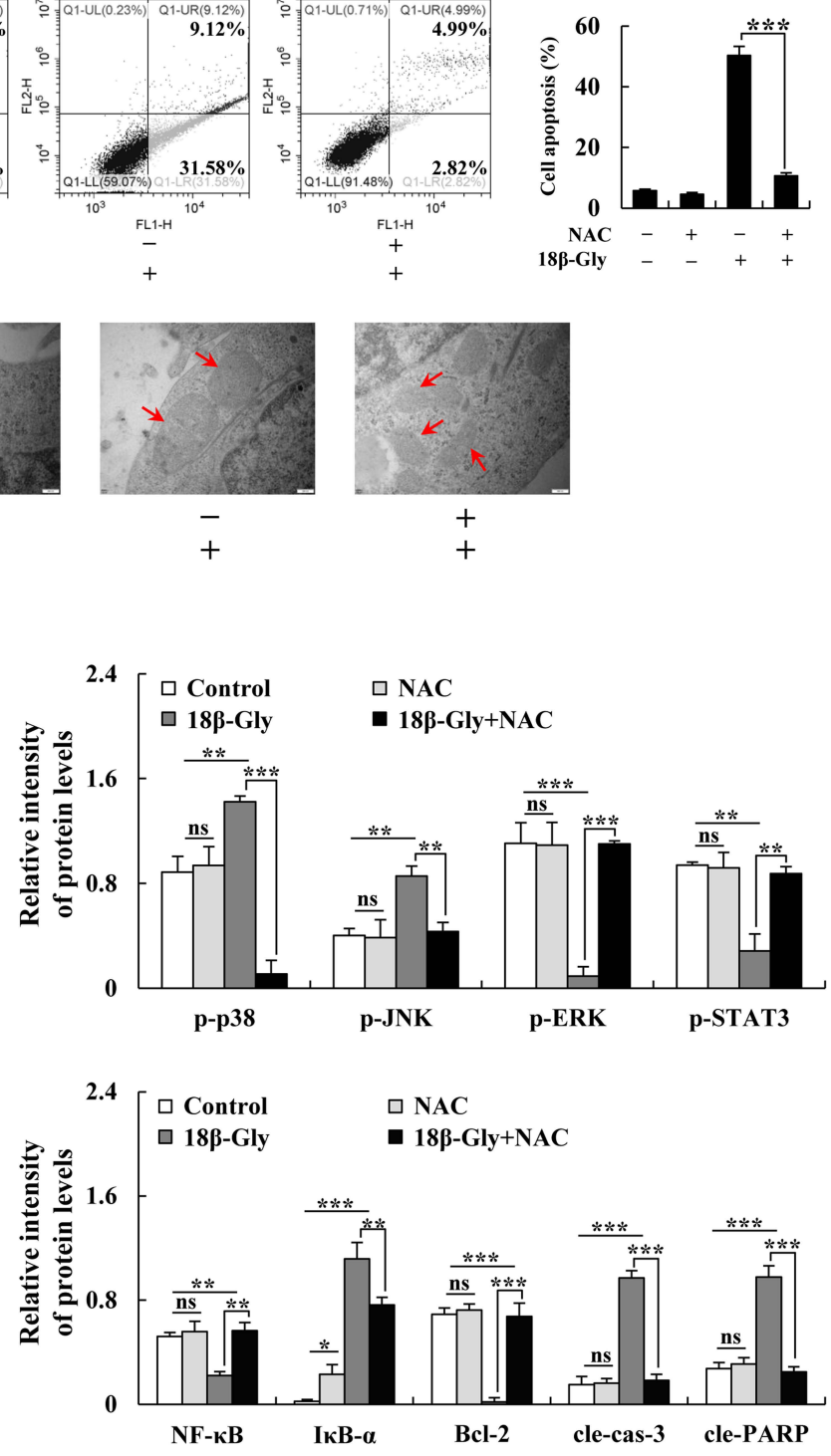

Figure 4 Effects of I8 3 -Gly on ROS generation and inducing apoptosis of A549 cells. (A) A549 cells were treated with I8 3 -Gly, and intracellular ROS levels were measured by FCM. (B) IMR-90 normal cells were treated with I8 8 -Gly, and intracellular ROS levels were measured by FCM. (C) A549 cells were treated with NAC and I8 $\beta$-Gly. Then the percentage of apoptotic cells was detected by FCM. (D) A549 cells were treated with NAC and I8 $\beta$-Gly. Next, mitochondrial morphology was observed by a transmission electron microscope, the morphological changes of mitochondria occurred at the arrow marks. (E) A549 cells were treated with I8 $\beta$-Gly and NAC, after which the expression levels of MAPKs, STAT3, NF-кB, cle-cas-3, and cle-PARP were detected by Western blotting. $\beta$-actin was used as the loading control. ns, not significant, $* P<0.05, * * P<0.01$, $* * * P<0.001$ vs $0 \mathrm{~h}$ or the NAC $+18 \beta$-Gly group. 
A

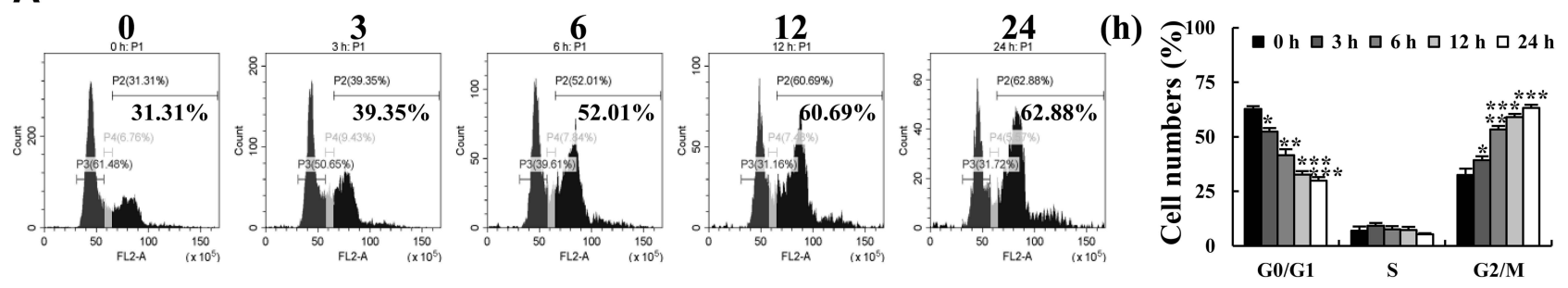

B

$\begin{array}{llllll}0 & 3 & 6 & 12 & 24 & \text { (h) }\end{array}$
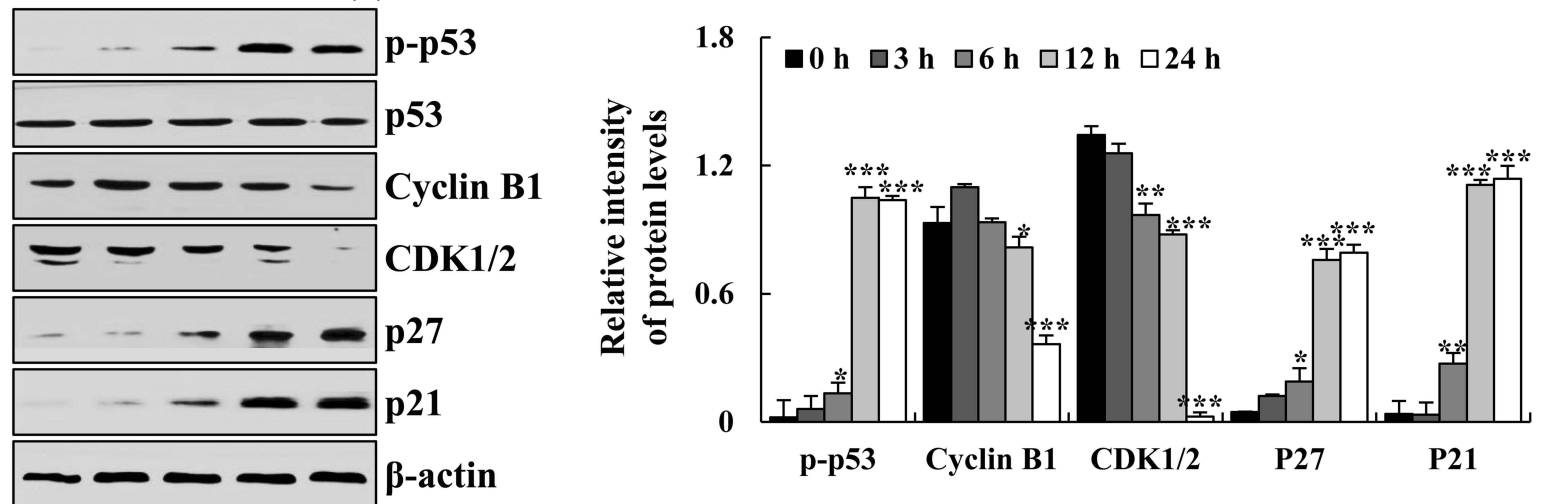

C
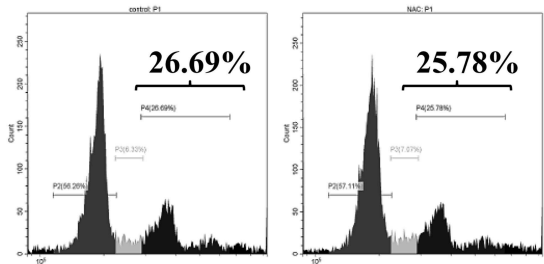

18ß-Gly

NAC

$$
-
$$$$
-
$$

$$
+
$$$$
-
$$

\section{D}

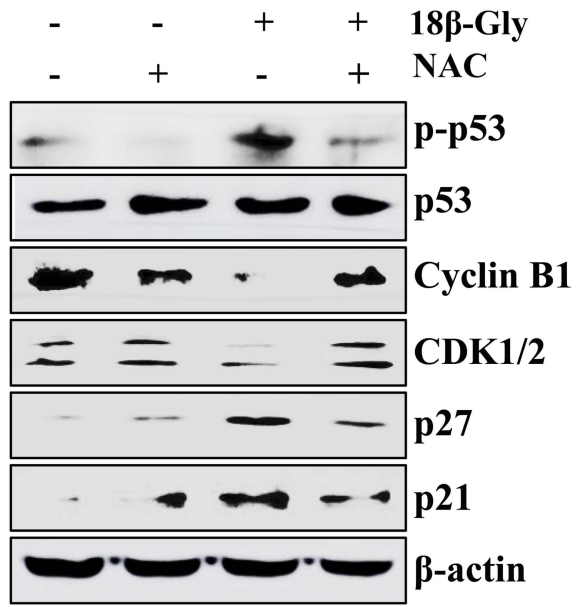

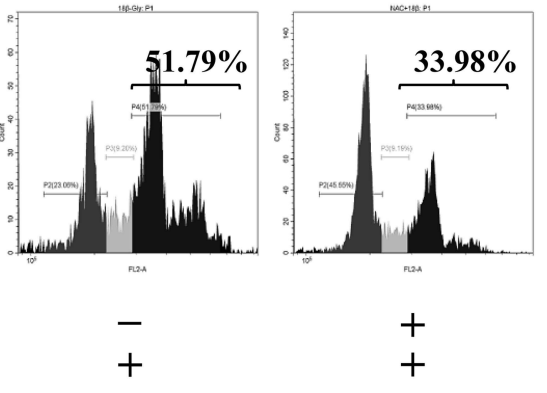
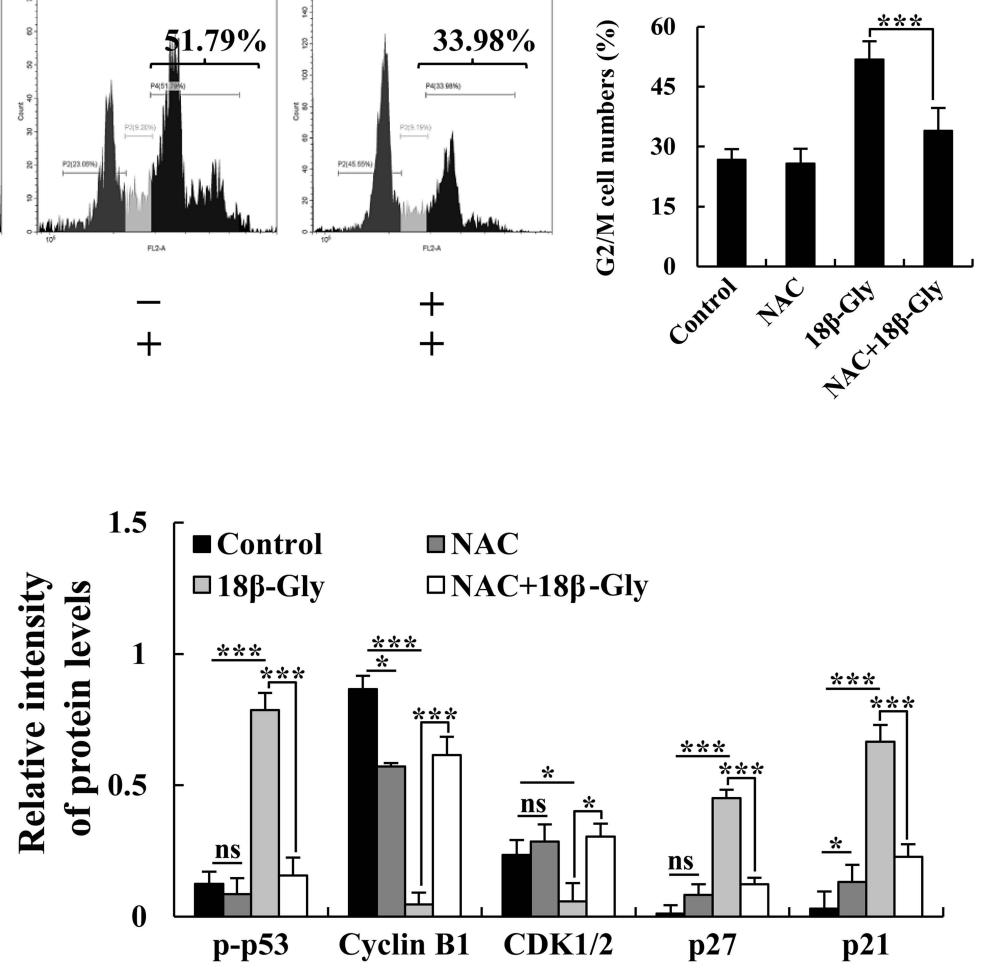

Figure 5 Effects of $18 \beta-G l y$ on the cell cycle in A549 cells. (A) The percentage of cell cycle as detected by FCM. (B) Expression levels of G2/M cell cycle-related proteins

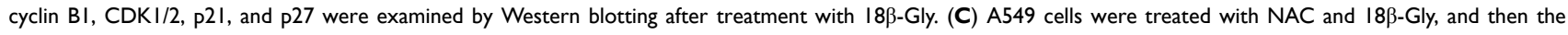
percentage of cell cycle was detected by flow cytometry. (D) A549 cells were treated with I8ß-Gly and NAC, after which the expression levels of cyclin BI, CDKI/2, p2I, and p27 were detected by Western blotting. $\beta$-actin was used as the loading control. ns, not significant, $* P<0.05, * * P<0.01$, ***P $<0.00 \mathrm{I}$ vs $0 \mathrm{~h}$ or the NAC $+18 \beta-\mathrm{Gly}$ group. 


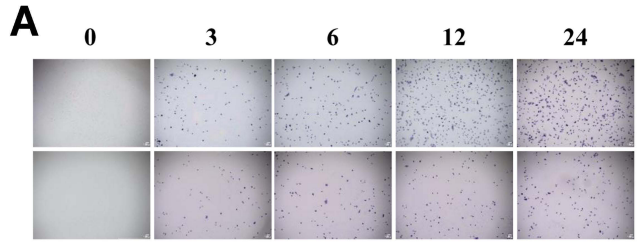

B 0

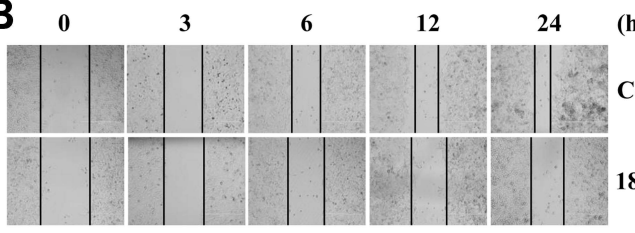

D

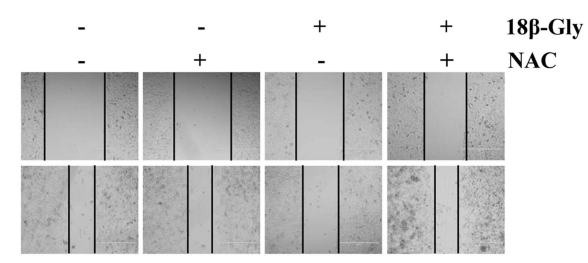

(h)

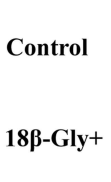

(h)
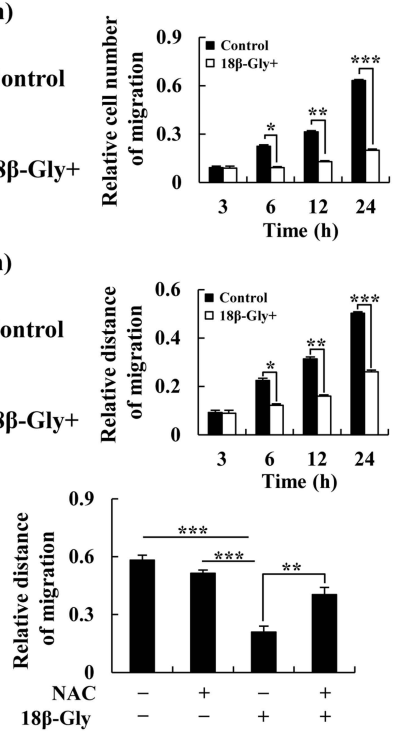

C
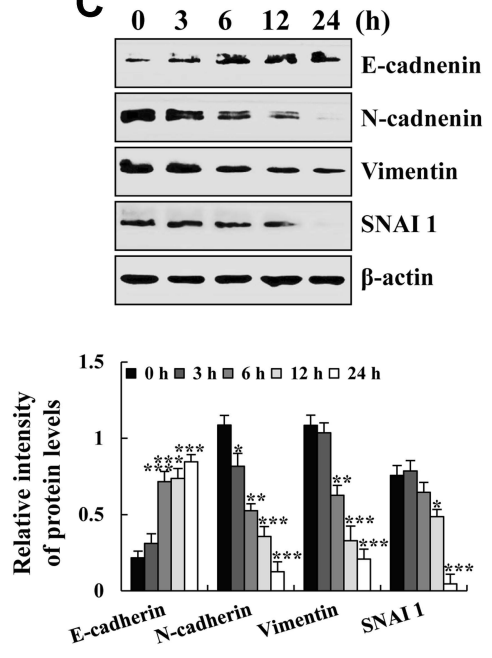

E.
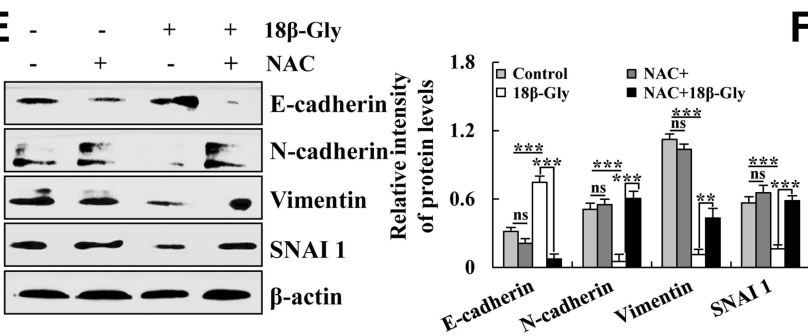

F .
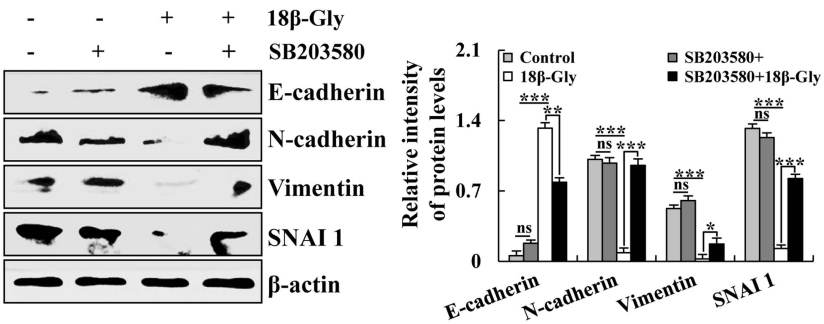

G.
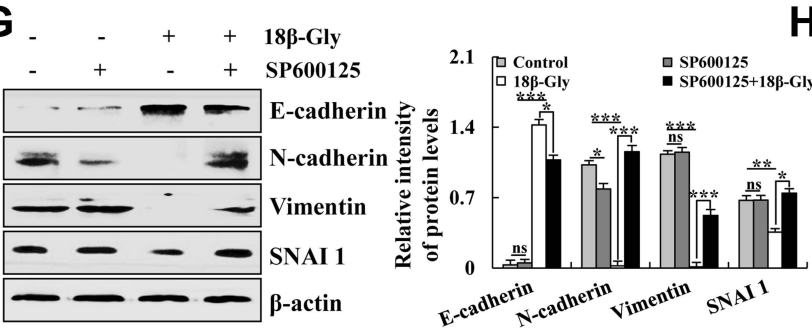

H
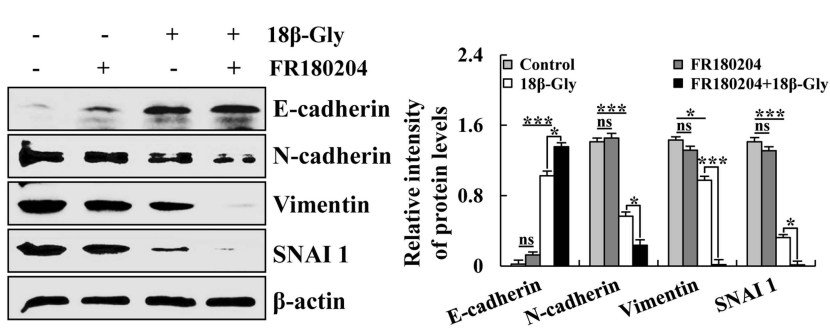

Figure 6 Effects of I8 8 -Gly on cell migration in A549 cells. (A) Transwell migration assay detects cell migration. (B) Cell migration was observed by an inverted microscope. (C) Expression levels of E-cadherin, N-cadherin, vimentin, and SNAI I were examined by Western blotting after treatment with I8ß-Gly. (D) A549 cells were treated with NAC and I8 8 -Gly, and then cell migration were observed by an inverted microscope. (E) A549 cells were treated with $18 \beta-G l y$ and NAC, after which the expression levels of E-cadherin, N-cadherin, vimentin, and SNAI I were detected by Western blotting. (F) A549 cells were treated with I8 3 -Gly and SB203580, after which the expression levels of E-cadherin, N-cadherin, vimentin, and SNAI I were detected by Western blotting. (G) A549 cells were treated with I8 3 -Gly and SP600I25, after which the expression levels of E-cadherin, N-cadherin, vimentin, and SNAI I were detected by Western blotting. (H) A549 cells were treated with I8 3 -Gly and FRI80204, and the expression levels of E-cadherin, $N$-cadherin, Vimentin, and SNAI I were detected by Western blotting. $\beta$-actin was used as the loading control. ns, not significant, $* P<0.05$, $* * P<0.01$, ***P $<0.001$ vs $0 \mathrm{~h}$ or the $\mathrm{NAC}+18 \beta$-Gly group.

many diseases. ${ }^{17,18}$ A previous study revealed that $18 \beta$ Gly induced apoptosis by regulating the PI3K/Akt and NF$\kappa \mathrm{B}$ signaling pathways in prostate carcinoma cells. ${ }^{19}$ Another study demonstrated that $18 \beta$-Gly induced apoptosis via the $\mathrm{Akt} / \mathrm{FOXO} \mathrm{a} / \mathrm{Bim}$ signaling pathway in breast cancer MCF-7 cells. ${ }^{20}$ To date, the underlying mechanisms of $18 \beta$-Gly in lung cancer cells remain unclear. In this study, we showed that $18 \beta$-Gly significantly reduced A549 cell viability and the side effects were lower than those of the 5-FU group.
We selected three normal cell types, among which, human lung fibroblasts (IMR-90) are extracted from embryonic cells, their primary properties have not transformed. It can directly reflect the toxicity effects to the human lung in the toxicity study of compound and has higher sensitivity and accuracy. During the absorption process, the drug will pass through the gastrointestinal tract. Some drugs will be metabolized by enzymes secreted by the gastrointestinal mucosa. In addition, kidney is an important organ of the human body. Its basic function is to remove metabolites and some wastes 
and poisons in the body. Therefore, we chose the IMR-90, GES-1, and 293T cells as controls.

Next, we detected the underlying molecular mechanism of $18 \beta$-Gly in lung cancer A549 cells.

Apoptosis is usually induced by chemotherapeutics and plays a vital role in the clinical treatment of human cancer. ${ }^{21-23}$ When cells undergo apoptosis, the $\Delta \psi_{\mathrm{m}}$ disappears, membrane permeability changes, a large amount of cytochrome $\mathrm{C}$ is released, and caspase 3 is cleaved. The Bcl2 family of proteins are the major regulators of cytochrome $\mathrm{C}$ release from the outer membrane of mitochondria into the cytoplasm. In addition, Bcl-2 and BAD also play regulatory roles in apoptosis. ${ }^{24-27}$ In this study, we found that $18 \beta$-Gly induced apoptosis via a mitochondria-dependent pathway.
Accumulating evidence has shown that apoptosis is regulated by many signaling pathways, such as MAPK, STAT3, and NF- $\kappa B .{ }^{28-30}$ MAPKs are critical for the transduction of signals from the cell surface to the nucleus. Among the members of the MAPK family, ERK is mainly responsible for the control of growth and differentiation, and JNK and p38 have roles in apoptosis as well as inflammation, growth, and differentiation. ${ }^{31-34}$ The STAT family of proteins is localized in the cytoplasm and can translocate to the nucleus and bind to DNA after activation. ${ }^{35,36}$ They have dual functions of signal transduction and transcription regulation. Among the STAT family members, STAT3 is most closely related to malignancies and participates in the signal transduction

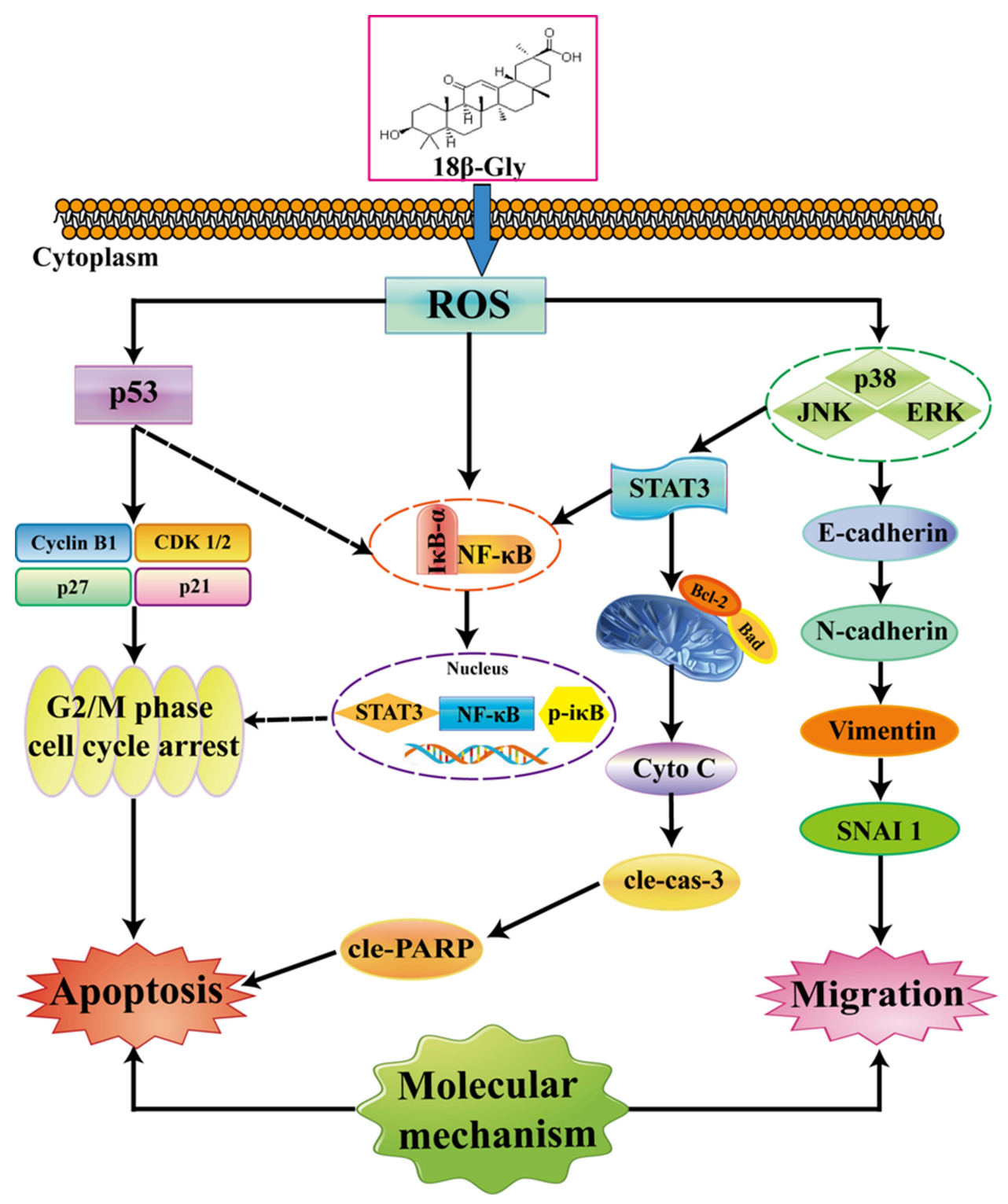

Figure 7 Mechanisms underlying the anti-cancer effects of I8ß-Gly on A549 human lung cancer cells. 
process of many cytokines. NF- $\kappa \mathrm{B}$, an important nuclear transcription factor in cells, induces apoptosis by regulating the cell cycle of cancer cells. ${ }^{37,38}$ Our results indicate that $18 \beta$-Gly regulates the MAPK/STAT3/NF- $\kappa$ B signaling pathways, and MAPK is upstream of the STAT3 signaling pathway.

ROS is a second messenger that regulates signal transduction pathways related to cell proliferation, differentiation, and apoptosis. ${ }^{39,40}$ In this study, we investigated the relationship between ROS and apoptosis, cell cycle, and cell migration-related signaling pathways. The results showed that $18 \beta$-Gly had a pro-oxidation effect on A459 cells, while $18 \beta$-Gly had an anti-oxidation effect on IMR90 human embryonic lung fibroblasts. We believe that the mechanism of action of 18 $\beta$-Gly in normal and cancer cells is different, involving different signaling pathways, and the specific mechanism needs to be further studied.

When DNA damage occurs in the G2 phase, cells undergo G2/M phase cell cycle arrest, degradation of the CDK1-cyclin $\mathrm{B} 1$ complex is inhibited, and the expression levels of p53 and p21 are increased. ${ }^{41}$ Our results showed that $18 \beta$-Gly induced G2/M cell cycle arrest; decreased the expression levels of cyclin B1 and CDK1/2; and increased the levels of p-p53, p21, and p27. In addition, ROS participated in regulating G2/ $\mathrm{M}$ cell cycle arrest induced by $18 \beta-$ Gly.

EMT modifies adhesion molecules expressed by the cell, which then adopt an invasive behavior, playing an essential role in cancer invasion and metastasis. E-cadherin, $\mathrm{N}$-cadherin, vimentin, and SNAI 1 are involved in the EMT process. ${ }^{42,43}$ In this study, we showed that $18 \beta$-Gly upregulated the expression levels of E-cadherin, and downregulated the expression levels of $\mathrm{N}$-cadherin, vimentin, and SNAI 1. We also found that ROS and MAPK were involved in the process of $18 \beta$-Gly-mediated inhibition of cell migration. These results further confirm the ability of $18 \beta$-Gly to inhibit lung cancer cell migration.

In conclusion, the results of this study demonstrated that $18 \beta$-Gly induced apoptosis and G2/M cell cycle arrest and inhibited migration via the ROS/MAPK/STAT3/NF$\kappa \mathrm{B}$ signaling pathways in A549 lung cancer cells (Figure 7). This is the first study to show the molecular mechanisms underlying the anticancer effects of $18 \beta$-Gly on lung cancer. Thus, $18 \beta$-Gly has the potential to be used as a chemopreventive agent for lung cancer.

\section{Acknowledgments}

We thank LetPub (www.letpub.com) for its linguistic assistance during the preparation of this manuscript.

\section{Funding}

This work was supported by the central government supports local college reform and development fund talent training projects (2020GSP16), the Heilongjiang Farms \& Land Reclamation Administration Support Project for Key Scientific Research (HKKYZD190705), the Heilongjiang Bayi Agricultural University Support Program for "San Zong" (TDJH201905), the Heilongjiang Touyan Innovation Team Program (2019HTY078), and Project for Heilongjiang Bayi Agricultural University (XDB202012), and the Heilongjiang Province College Student Innovation and Entrepreneurship Training Program Project (202010223004, 202010223001).

\section{Disclosure}

The authors declare they have no conflict of interest.

\section{References}

1. Brody H. Lung cancer. Nature. 2014;513(7517):S1. doi:10.1038/ 513S1a

2. Schabath MB, Cote ML. Cancer progress and priorities: lung cancer. Cancer Epidemiol Biomarkers Prev. 2019;28(10):1563-1579. doi:10.1158/1055-9965.EPI-19-0221

3. Hirsch FR, Scagliotti GV, Mulshine JL, et al. Lung cancer: current therapies and new targeted treatments. Lancet. 2017;389:299-311. doi:10.1016/S0140-6736(16)30958-8

4. Herbst RS, Morgensztern D, Boshoff C. The biology and management of non-small cell lung cancer. Nature. 2018;553 (7689):446-454. doi:10.1038/nature25183

5. An W, Lai H, Zhang Y, et al. Apoptotic Pathway as the Therapeutic Target for Anticancer Traditional Chinese Medicines. Front Pharmacol. 2019;10:758.

6. Man S, Gao W, Wei C, et al. Anticancer drugs from traditional toxic Chinese medicines. Phytother Res. 2012;26(10):1449-1465. doi:10.1002/ptr.4609

7. Matsumoto T, Sakurai K, Tanaka A, et al. The anti-ulcer agent, irsogladine, increases insulin secretion by MIN6 cells. Eur J Pharmacol. 2012;685(1-3):213-217. doi:10.1016/j.ejphar.2012.04.005

8. Fan B, Jiang B, Yan S, et al. Anti-Inflammatory 18ß-Glycyrrhetinin Acid Derivatives Produced by Biocatalysis. Planta Med. 2019;85 (1):56-61. doi:10.1055/a-0662-0296

9. Song D, Gao Y, Wang R, et al. Downregulation of c-FLIP, XIAP and Mcl-1 protein as well as depletion of reduced glutathione contribute to the apoptosis induction of glycyrrhetinic acid derivatives in leukemia cells. Cancer Biol Ther. 2010;9(2):96-108. doi:10.4161/cbt.9.2.10287

10. Cai H, Chen X, Zhang J, et al. 18ß-glycyrrhetinic acid inhibits migration and invasion of human gastric cancer cells via the ROS/ PKC- $\alpha$ /ERK pathway. J Nat Med. 2018;72(1):252-259. doi:10.1007/ s11418-017-1145-y

11. Zhang J, Wang X, Vikash V, et al. ROS and ROS-Mediated Cellular Signaling. Oxid Med Cell Longev. 2016;2016:4350965. doi:10.1155/ 2016/4350965

12. Moloney JN, Cotter TG. ROS signalling in the biology of cancer. Semin Cell Dev Biol. 2018;80:50-64.

13. D'Autréaux B, Toledano MB. ROS as signalling molecules: mechanisms that generate specificity in ROS homeostasis. Nat Rev Mol Cell Biol. 2007;8(10):813-824. doi:10.1038/nrm2256 
14. Li Y, Chen F, Chen J, et al. Disulfiram/Copper Induces Antitumor Activity against Both Nasopharyngeal Cancer Cells and Cancer-Associated Fibroblasts through ROS/MAPK and Ferroptosis Pathways. Cancers. 2020;12(1):138. doi:10.3390/cancers 12010138

15. Bragado P, Armesilla A, Silva A, et al. Apoptosis by cisplatin requires p53 mediated p38alpha MAPK activation through ROS generation. Apoptosis. 2007;12(9):1733-1742. doi:10.1007/s10495007-0082-8

16. Yang HL, Thiyagarajan V, Shen PC, et al. Anti-EMT properties of CoQ0 attributed to PI3K/AKT/NFKB/MMP-9 signaling pathway through ROS-mediated apoptosis. J Exp Clin Cancer Res. 2019;38 (1):186. doi:10.1186/s13046-019-1196-x

17. Lefaki M, Papaevgeniou N, Tur JA, et al. The dietary triterpenoid 18 $\alpha$-Glycyrrhetinic acid protects from MMC-induced genotoxicity through the ERK/Nrf2 pathway. Redox Biol. 2020;28:101317. doi:10.1016/j.redox.2019.101317

18. Su L, Wang Z, Huang F, et al. 18ß-Glycyrrhetinic acid mitigates radiation-induced skin damage via NADPH oxidase/ROS/ p38MAPK and NF-kB pathways. Environ Toxicol Pharmacol. 2018;60:82-90. doi:10.1016/j.etap.2018.04.012

19. Sun Y, Jiang M, Park PH, et al. Transcriptional suppression of androgen receptor by $18 \beta$-glycyrrhetinic acid in $\mathrm{LNCaP}$ human prostate cancer cells. Arch Pharm Res. 2020;43(4):433-448. doi:10.1007/ s12272-020-01228-z

20. Kroemer G, Pouyssegur J. Tumor cell metabolism: cancer's Achilles' heel. Cancer Cell. 2008;13(6):472-482. doi:10.1016/j. ccr.2008.05.005

21. Sharma G, Kar S, Palit S, et al. 18ß-glycyrrhetinic acid induces apoptosis through modulation of $\mathrm{Akt} / \mathrm{FOXO} 3 \mathrm{a} / \mathrm{Bim}$ pathway in human breast cancer MCF-7 cells. J Cell Physiol. 2012;227 (5):1923-1931. doi:10.1002/jcp.22920

22. Gerl R, Vaux DL. Apoptosis in the development and treatment of cancer. Carcinogenesis. 2005;26(2):263-270. doi:10.1093/carcin/ $\operatorname{bgh} 283$

23. Wong RS. Apoptosis in cancer: from pathogenesis to treatment. $J$ Exp Clin Cancer Res. 2011;30(1):87. doi:10.1186/1756-9966-30-87

24. Sinha K, Das J, Pal PB, et al. Oxidative stress: the mitochondria-dependent and mitochondria-independent pathways of apoptosis. Arch Toxicol. 2013;87(7):1157-1180.

25. Ashkenazi A, Fairbrother WJ, Leverson JD, et al. From basic apoptosis discoveries to advanced selective BCL-2 family inhibitors. Nat Rev Drug Discov. 2017;16(4):273-284. doi:10.1038/nrd.2016.253

26. Delbridge AR, Grabow S, Strasser A, et al. Thirty years of BCL-2: translating cell death discoveries into novel cancer therapies. Nat Rev Cancer. 2016;16(2):99-109. doi:10.1038/nrc.2015.17

27. Bock FJ, Tait SWG. Mitochondria as multifaceted regulators of cell death. Nat Rev Mol Cell Biol. 2020;21(2):85-100. doi:10.1038/ s41580-019-0173-8

28. Wagner EF, Nebreda AR. Signal integration by JNK and p38 MAPK pathways in cancer development. Nat Rev Cancer. 2009;9 (8):537-549. doi:10.1038/nrc2694

OncoTargets and Therapy

\section{Publish your work in this journal}

OncoTargets and Therapy is an international, peer-reviewed, open access journal focusing on the pathological basis of all cancers, potential targets for therapy and treatment protocols employed to improve the management of cancer patients. The journal also focuses on the impact of management programs and new therapeutic

Submit your manuscript here: https://www.dovepress.com/oncotargets-and-therapy-journal
29. Yu H, Pardoll D, Jove R. STATs in cancer inflammation and immunity: a leading role for STAT3. Nat Rev Cancer. 2009;9(11):798-809. doi: $10.1038 / \mathrm{nrc} 2734$

30. Shostak K, Chariot A. EGFR and NF-kB: partners in cancer. Trends Mol Med. 2015;21(6):385-393. doi:10.1016/j.molmed.2015.04.001

31. Kurtzeborn K, Kwon HN, Kuure S. MAPK/ERK Signaling in Regulation of Renal Differentiation. Int J Mol Sci. 2019;20(7):1779. doi:10.3390/ijms20071779

32. Yen JH, Lin $\mathrm{CY}$, Chuang $\mathrm{CH}$, et al. Nobiletin Promotes Megakaryocytic Differentiation through the MAPK/ERK-Dependent EGR1 Expression and Exerts Anti-Leukemic Effects in Human Chronic Myeloid Leukemia (CML) K562 Cells. Cells. 2020;9 (4):877. doi:10.3390/cells9040877

33. Arthur JS, Ley SC. Mitogen-activated protein kinases in innate immunity. Nat Rev Immunol. 2013;13(9):679-692. doi:10.1038/ nri3495

34. Wu T, Chen J. p38 MAPK reins in right ventricular growth. $J$ Clin Invest. 2020;130(10):5109-5111. doi:10.1172/JCI140793

35. Reich NC, Liu L. Tracking STAT nuclear traffic. Nat Rev Immunol. 2006;6(8):602-612. doi:10.1038/nri1885

36. Banerjee S, Biehl A, Gadina M, et al. JAK-STAT Signaling as a Target for Inflammatory and Autoimmune Diseases: current and Future Prospects. Drugs. 2017;77(5):521-546. doi:10.1007/s40265017-0701-9

37. Fan Y, Mao R, Yang J. NF- $\kappa B$ and STAT3 signaling pathways collaboratively link inflammation to cancer. Protein Cell. 2013;4 (3):176-185. doi:10.1007/s13238-013-2084-3

38. Perkins ND. The diverse and complex roles of NF- $\mathrm{KB}$ subunits in cancer. Nat Rev Cancer. 2012;12(2):121-132. doi:10.1038/nrc3204

39. Mittler R. ROS Are Good. Trends Plant Sci. 2017;22(1):11-19. doi:10.1016/j.tplants.2016.08.002

40. Luo Z, Xu X, Sho T, et al. ROS-induced autophagy regulates porcine trophectoderm cell apoptosis, proliferation, and differentiation. $A m$ J Physiol Cell Physiol. 2019;316(2):C198-C209. doi:10.1152/ ajpcell.00256.2018

41. Reddy D, Kumavath R, Ghosh P, et al. Lanatoside C Induces G2/M Cell Cycle Arrest and Suppresses Cancer Cell Growth by Attenuating MAPK, Wnt, JAK-STAT, and PI3K/AKT/mTOR Signaling Pathways. Biomolecules. 2019;9(12):792. doi:10.3390/biom9120792

42. Xu M, Wang J, Xu Z, et al. SNAI1 Promotes the Cholangiocellular Phenotype, but not Epithelial-Mesenchymal Transition, in a Murine Hepatocellular Carcinoma Model. Cancer Res. 2019;79 (21):5563-5574.

43. Wang W, Dong L, Zhao B, et al. E-cadherin is downregulated by microenvironmental changes in pancreatic cancer and induces EMT. Oncol Rep. 2018;40(3):1641-1649. agents and protocols on patient perspectives such as quality of life, adherence and satisfaction. The manuscript management system is completely online and includes a very quick and fair peer-review system, which is all easy to use. Visit http://www.dovepress.com/ testimonials.php to read real quotes from published authors. 